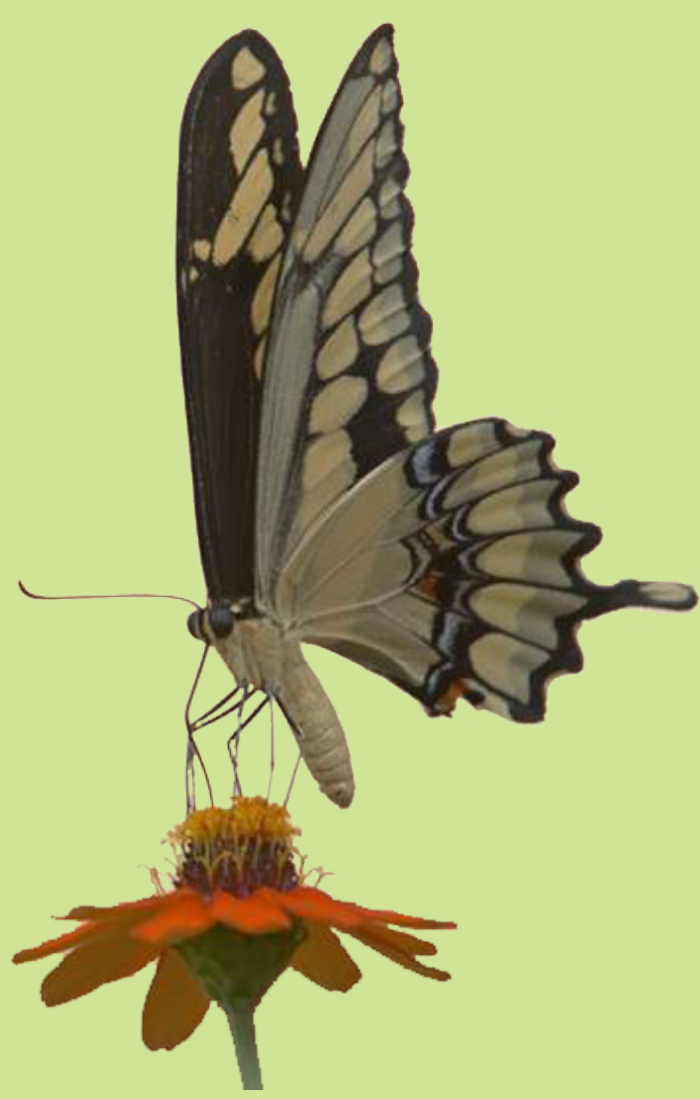

\title{
Reflections on the Ecology of Landscapes
}

Viktor J. BRUCKMAN (Ed.)

KIOES Opinions 10 (2020)

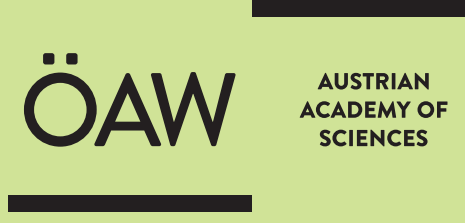





\section{Reflections on the Ecology of Landscapes}


KIOES Opinions 10 (2020): 1-24.

doi: 10.1553/KIOESOP_010

Imprint:

KIOES Opinions are published by the Commission for Interdisciplinary Ecological Studies (KIOES) of the Austrian Academy of Sciences (OeAW). KIOES publishes current opinions written, initiated or invited by KIOES related to topical subjects on an irregular basis in KIOES Opinions. The target audience includes scientists, policy makers and the public. Opinions expressed in this article are solely those of the author(s), and they do not necessarily reflect in any way those of KIOES or OeAW.

More information about KIOES and download of KIOES Opinions at http://www.oeaw.ac.at/kioes

Managing Editor:

Viktor J. Bruckman

Layout: Karin Windsteig

Cover photo credit: Fotofolia

Editorial office:

Commission for Interdisciplinary Ecological Studies, OeAW, Dr. Ignaz Seipel-Platz 2, 1010 Vienna E-mail: viktor.bruckman@oeaw.ac.at, +431515813200 


\title{
Table of Contents
}

\author{
VIKTOR J. BRUCKMAN
}

Foreword

GERHARD GLATZEL

Half a Century in Forest Science - Changing Focus, Burning Issues, Forgotten Lessons . VI

\section{GENE E. LIKENS}

Lessons Learned from Long-term Ecosystem Studies ............................................ 1

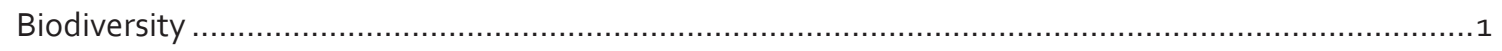

Acid Rain

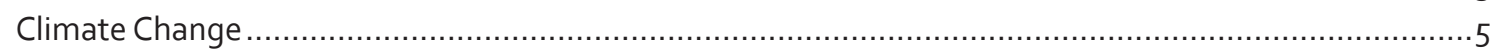

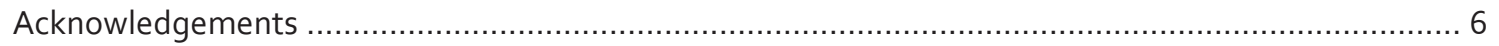

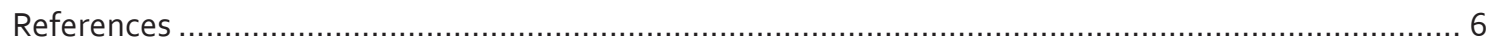

MARINA FISCHER-KOWALSKI

Global Use of Natural Resources: Are we Heading for a New Sociometabolic Regime? .......... 7

Distinguishing Sociometabolic Regimes ...................................................................................

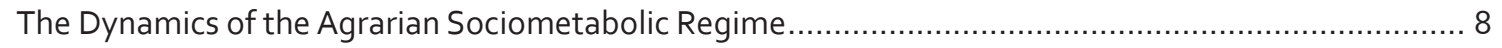

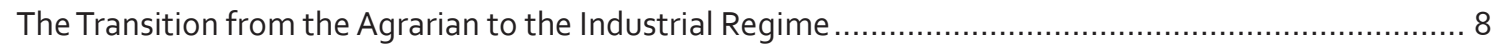

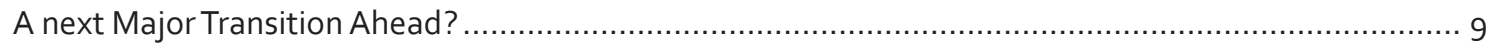

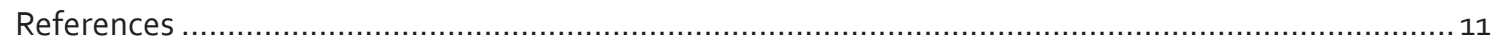

\section{CHRISTIAN KÖRNER}

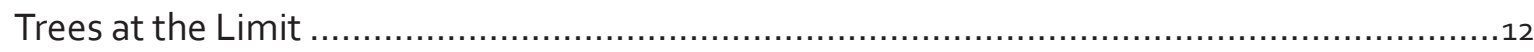

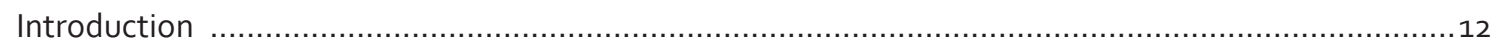

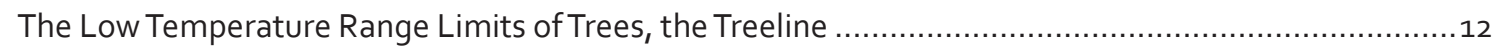

The Low Temperate Range Limits of Temperate Deciduous Tree Species .......................................14

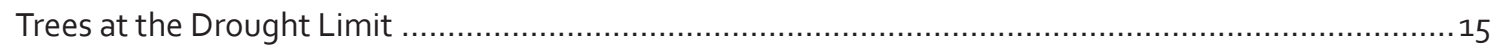

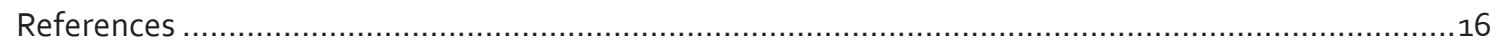

\section{Phemo Karen Kgomotso}

Land Degradation and Rural Poverty in Africa .......................................................... 17

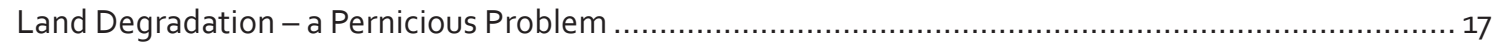

Links between Land Degradation and Poverty in Africa ................................................................. 17

Addressing Land Degradation: Sustainable Land Management and Restoration .................................19

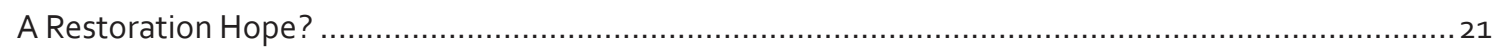

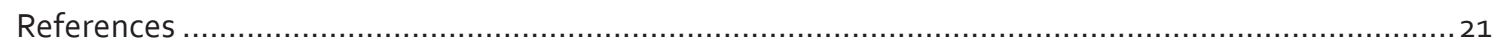

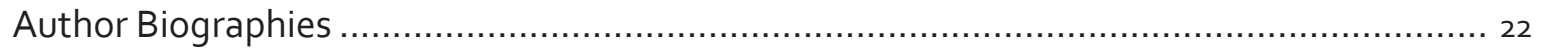





\section{Foreword}

VIKTOR J. BRUCKMAN

The current volume of the KIOES OPINIONS represents a ramble through aspects of land use, land use change and its ecological and social consequences. Readers will note the scientific broadness among and interdisciplinarity within each of the contributions. This is on purpose, since they resemble summaries of the lectures given during the festive symposium "Land Use Ecology", organized by the Austrian Academy of Sciences (OeAW), the International Institute of Applied Systems Analysis (IIASA), the University of Natural Resources and Life Sciences (BOKU) and the Natural History Museum Vienna (NHM). The symposium was organized in honour of the $80^{\text {th }}$ birthday of Professor Gerhard Glatzel, an outstanding scientific scholar. As one can read from his own notes, he is open-minded, thoughtful and a good example of a lateral thinker. Consequently, organizing this event, which took place on $19^{\text {th }}$ of November, 2019 at the premises of the Natural History Museum, Vienna, was not an easy task for the organizing committee. Our aim was to reflect both the scientific excellence of his career, while providing an overview of the extent of the activities and scientific interests Professor Glatzel tackled in his professional career. A key aim was to account for his unique gift to link these in a meaningful way. This is indeed necessary to address a range of issues in the complex topical field of land use, ecology and society, which are challen- ging aspects. Many ecosystems are close to tipping points that prevent a return to the current stage once left behind. Climate change, the biodiversity crisis and a growing demand for natural resources are just some of the interlinked key components, which will determine our future world. We hope and wish that this symposium not only appropriately honoured an outstanding scholar, but also raised awareness that complex ecological problems require unique solutions, based on interdisciplinary scientific discourse and often out-of-the-box thinking.

At this point, I would like to thank all speakers, who provided a summary of their talk in written form, so we were able to produce this volume. Organizing such an event would have been impossible without a strong and dedicated organizing committee, hence my gratitude goes to its members Torsten Berger, Georg Gratzer, Klaus Katzensteiner (BOKU University), Christian Köberl (University of Vienna and formerly NHM) and Florian Kraxner (IIASA), who spent much of their time to contribute to the great success of this event. Funding was achieved through the generous support of the organizing institutions.

May this volume be a stimulating read and encourage professionals and the interested public alike to look and think beyond!

On behalf of the organizing committee Viktor J. Bruckman Vienna, September 10, 2020 


\title{
Half a Century in Forest Science - Changing Focus, Burning Issues, Forgotten Lessons
}

\author{
GERHARD GLATZEL
}

When I was a student of forest engineering at BOKUUniversity in the early 1960ies, Anton Krapfenbauer (1924-2020), Associate Professor of Forest Soil and Site Ecology, kindled my interest in research and experimentation. He was full of ideas and liked to challenge textbook knowledge and traditional approaches. He knew of my interest in analytical chemistry and allowed me to work in his initially very modest, one-room lab. At that time, forest soils, forest site ecology, and mineral nutrition in forests were our focus. Restoring productivity in forests degraded by historic biomass extraction was a political and economic target in the first decades after World War II.

By a fortunate coincidence, I had witnessed historic forest use as a schoolboy. My father was a forest manager, and my parents tended a home garden to feed three hungry boys. It provided potatoes, vegetables as well as fruits, and we had chickens, ducks, rabbits, and a pig, fed on food scraps. In contemporary terminology, it was organic and sustainable. I remember that we went to the forest every fall to fill huge burlap bags with leaf litter for composting with vegetable residues to enrich the soil in the garden. My father called it jokingly "forest eating." Being the son of a forest manager had other benefits too. I liked to accompany my father to his work, but when the weather was poor, or his work was dangerous, I had to wait in the houses of the local Forest Rangers until my father returned from the woods. My favorite place was an old forest-office building with a bookcase harboring Brehm's Animal Life and Kerner von Marilaun's Plant Life - thick volumes with exciting pictures showing me the wonders of the animal and plant world - delicious food for my innate curiosity. I became addicted to the musty smell of books kept in unheated rooms and the sight of the occasional Book Scorpion. The old library smell has become rare, but at times, I still encounter it and instantly remember my days as a schoolboy in the library of a forester's house.

But back to my academic career. After my graduation, my mentor Anton Krapfenbauer motivated me to apply for a Fulbright Grant to study in the US. I got a Research Assistant Grant at Utah State University, where TW. Daniel, Professor of Silviculture, hosted me and became a fatherly friend. Lessons in statistics, analytical chemistry, and plant physiology proved to be very useful after my return to a meagerly paid temporary helper job in the lab of Dr. Krapfenbauer at BOKU. Fortunately, Krapfenbauer was appointed Full Professor soon after my return to Vienna and negotiated successfully for lab equipment and staff, which provided me with a fully paid assistant position and vastly improved laboratory equipment. Two additional assistant jobs allowed for the hiring of Herbert Hager, trained in forest meteorology in Munich, and of Hubert Sterba, an expert in forest growth modeling and statistics. A little later, Monika Sieghardt, a botanist with a particular interest in lab management, joined the team.

In the first years, nutrient deficiencies of forest trees, their detection by foliar analysis, and their relief by fertilizer use were the key issues. To overcome the statistical bottleneck of limited replications, we started to use single trees in a randomized arrangement as treatment units. Many experiments were on afforestation of nutrient-deficient or climatically harsh sites in the mountains. The idea was to stimulate growth to bring the trees out of the reach of deer or ground frosts. In nutrient deficient spruce-stands with a thick layer of raw-humus, liming accelerated decomposition and made nitrogen and phosphorous 
available. At that time, nitrogen deficiency was still a problem in forests, as a consequence of litter raking practiced to transfer nutrients from forests to agriculture. We cut up a lot of trees in wood, bark, branches, and leaves to demonstrate the nutrient content in various compartments, as Paul Duvigneaud had demonstrated. Justus von Liebig had already stressed in the $19^{\text {th }}$ century, that wood has a minimal nutrient content compared to agricultural food crops. Most of the nutrients in a forest exist in the canopy and the soil. For that reason, litter-raking was detrimental to forest productivity and health. As forest nutrition was an issue at many universities at that time, we soon came in contact with colleagues in Germany, France, Sweden, and the US and became part of an international network. Wittich, Zoettl, Fiedler, Ulrich, Rehfuess, Kreuzer, Huettl, in Germany, Bonneau in France, Duvigneaud in Belgium, Tamm in Sweden, and Cole in the United States, to mention just a very view, were well known at that time.

Beyond the rather straight forward fertilizer trials, physiological aspects of tree nutrition and tree growth aroused my interest. Hanno Richter (later Professor at BOKU), Walter Larcher (Innsbruck), Christian Körner (Innsbruck and Basel), and Tom Hinckley (University of Washington) helped me in many discussions to understand physiological processes. The relationship between nutritional status, water use, and the growth of plants was a particularly interesting question. There was a lot of research on this in agriculture. Still, there was the problem that changing mineral nutrition caused an immediate growth response in herbaceous plants, which confounded the causal interpretation of the effect of nutritional status on water use efficiency. I realized that conifers offered an opportunity to overcome the problem. Many conifers have a single growth flush in spring but then provide a time window for manipulating nutrient status when their foliage does not respond by growth. I could show that water-use efficiency is affected by mineral nutrition and that plants with balanced nutritional status need less water for biomass increment. These experiments were the basis for a lengthy, German language monography required at that time for my "venia docendi", which rests peacefully in the university library ever since.

During the 1970ties, the scientific focus at the Institute of Forest Ecology expanded from the study of specific processes to research at the ecosystem le- vel. Forests are incredibly complex systems, and to understand their dynamics abiotic, as well as biotic and stochastic disturbances, had to be considered. A sound basis was the experience in site classification and site mapping, which were core activities of our institute. We were strong in soil science, forest nutrition, vegetation science, and atmospheric interactions but had little expertise in biotic factors. Luckily Erwin Führer and later Axel Schopf and Erhard Halmschlager from the Institute of Forest Pathology offered their collaboration. The impact of forest management practices, such as the choice of tree species or whole tree harvesting, were essential research questions.

In the early 1980ties, the focus at the Institute of Forest Ecology changed again. Air pollution had reached a level that caused widespread damage to forests in parts of Europe and the US. "Waldsterben" (forest dieback) was the burning issue. The beechforest of the Vienna Woods offered a neat model for demonstrating pollutant deposition. In beech (Fagus sylvatica), intercepted precipitation flows down along the branches and the trunk and infiltrates the soil. For years we had shown our students that the infiltration zone is a rich microsite offering better water and nutrient supply to the forest floor vegetation. In 1979 we observed dieback of the groundcover at and downhill from the infiltration zone. Soils samples taken in a ten by ten $\mathrm{cm}$ grid showed severe acidification and depletion of nutrients. During the next years, "Acid Rain" was the topic of many diploma and doctoral theses. Two of them, Klaus Katzensteiner and Torsten Berger, are now professors at the Institute of Forest Ecology. Aside from the analysis of throughfall and stem-drain throughout the seasons and at different topographic positions, the effects of pollutant input on soil and trees were crucial issues. Gene Likens work on the biogeochemistry of forests was particularly inspiring and stimulating.

I collaborated with Helmut Löffler, in charge of air quality at the environment protection department of Vienna, which funded parts of our research, and with Hans Puxbaum, Institute of Analytical Chemistry of the Technical University of Vienna, who helped us with the analysis of trace pollutants. A worrying finding was that some precipitation samples from beech stands, close to the city of Vienna, contained excessive amounts of heavy metals, in particular, mercury, lead, and cadmium, as well as hydrochloric 
acids. We found the highest concentrations during winter days with fog over the city and south-easterly winds. We concluded that the two garbage incinerators in Vienna must contribute significantly. Garbage at that time contained polyvinyl chloride, and heaps of mercury, and lead batteries. Löffler reported these findings to the responsible department but could not convince them to take action. In 1985 I decided to go public, and we got a frontpage of the most popular newspaper, "Kronenzeitung". The next day I got a call from the office of the Mayor of Vienna, Helmut Zilk, asking me for a meeting. When I came to his office, he was furious about the fact that I had gone public, despite an existing co-operation with one of his departments. But then he listened for half an hour to my explanations and finally said that he would discuss the issue of filters with the responsible officials. Soon after that, there were filters installed, and now we have highly advanced air cleaners in all garbage incinerators in Vienna.

But there were disappointments too. When my student Erwin Sonderegger had finished his doctoral studies on the effects of air pollution on forests in 1983, he invited me to spend some days in his mountain hut in Vorarlberg. After a hefty dose of gentian schnapps, we discussed options for curbing air pollution and acid rain from the burning of fossil fuels. We came up with the idea that (1) equal access for all human beings to fossil fuel must be a human right, (2) mining of fossil fuel, a limited resource, must be restricted, and the permissible amount fixed in biannual sessions of the United Nations. We thought that restrictions on the source side - example OPEC would be much easier to implement than on the consumer side, as oil companies would not object to reducing production, because prices would rise with a shortage. The limited availability of fossil fuel would stimulate technological innovation, and the lower need in less industrialized tropical countries would lead to a flow of money into these countries for development. To our great disappointment, not a single newspaper wanted our manuscript, not even as a letter to the editor. Tragically, Erwin Sonderegger died in a paragliding accident soon after that. As long as the established climate protection approach does not reverse climate change, I still think our idea would have been worth a debate - but this is, of course, a biased assumption.
I skip the years of professor at BOKU and my function in the Austrian Science Fund, the European Science Foundation, and the various assignments I had in the Austrian Academy of Sciences, amongst them chairing KIOES (Commission for Interdisciplinary Ecological Studies) and the Austrian IIASA Committee. But I can not refrain from mentioning two engagements which rewarded me bounteous for administrative toil during the last decades of my professional life. After my admission to the Austrian Academy of Sciences as a Full Member, I decided that I should devote some of my time to students from countries that struggle to catch up in science and education. My function as chair of the Commission for Development Studies at the Academy helped me to establish worldwide contacts. Birgit Habermann, now a Scientist at ILRI, was a dedicated and knowledgeable assistant. Georg Gratzer, who advanced to a professor at the Institute of Forest Ecology at BOKU, started his career with work on the forests of the Bhutan Himalayas. Fieldwork in many countries of the globe showed me the diversity of forests as well as their multiple uses, and the interaction with students and people of different cultures repaid me with insight and friendship. I cannot list all the names here but thank them full-heartedly for what they gave to me. The establishment of an English language master curriculum in Mountain Forestry at BOKU is an achievement based on this work. The other engagement I like to mention is a sideline interest in the biology of mistletoes, fascinating parasitic flowering plants in the canopy of forests I had the chance to visit with my students. It started with a study on the physiology of Loranthus europaeus in Austria. Remembering a course in control systems during my studies at BOKU, I realized that a mistletoe on a host branch represents a second control system on a shared supply - a setup to be strictly avoided because it causes oscillations and loss of control. The resulting publication in Oecologia is one of my most cited papers. Interest in mistletoes is not mainstream, and only a small group of people works on mistletoes. Being accepted as a member of the group means becoming part of a tightly-knit family. The late Professor S. Balasubramaniam, Sri Lanka, who introduced me to tropical mistletoes, and Professor Bryan Barlow, Australia, became very close personal friends. 
But now I have to address the forgotten facts on biomass and carbon in forest ecosystems. In discussions on climate protection, the role of trees and forests is, unfortunately, often very simplified, neglecting scientific knowledge on forest nutrition and ecosystem function. Hundreds of published experiments in forest nutrition show that biomass production in many forests is not limited by $\mathrm{CO}_{2}$ but by mineral nutrients, nitrogen, and water, as well as pests and diseases. All too often, biofuel advocates assume that forests are only carbon limited, and the harvest of biomass has no adverse effects on productivity and forest ecosystem function. Forest owners struggling for economic survival in a market swamped by an excess of fallen timber will grab any opportunity the market offers. They are not to blame. However, investing taxpayer's money in technology to convert forest biomass into automotive fuels is the wrong approach. The available amounts are globally much too low, to halt climate change. The extraction of whole tree biomass has, however, scientifically proven adverse effects on many soil functions, e.g., water storage capacity, on biodiversity, and site productivity. It would be much better to use the money to support good forest practice by landowners and to subsidize technological development for alternative and better energy use. It is sobering to realize that torturing my students with exam questions on forest soil, nutrient cycling, with Justus von Liebig and with Mitscherlich had so little impact on decisions in climate change and energy politics.

Limited space allowed me to mention and thank just a few friends who accompanied me on my long and twisted path from country boy to Professor and Member of two Academies of Sciences. The many students and colleagues I could not mention, remain in my thoughts and in my heart. The most important persons in my life are my wife, Isolde, and my children. They endured my frequent absence when I worked in the lab or the forest, or the lack of attention when I was brooding over scientific problems. Isolde typed most of my manuscripts when typewriters were still in use and became later a critical proofreader of my texts. She shared my life for more than half a century and accompanied me as a keen observer to forests, mountains, and seas - scuba diving was our shared hobby - in remote countries.

Finally, I have to thank Viktor Bruckman, my engaged and prudent assistant, and dependable friend for his tireless help during my post-emeritus functions at the Academy! 


\title{
Lessons Learned from Long-term Ecosystem Studies
}

\author{
GENE E. LIKENS
}

The Hubbard Brook Ecosystem Study (HBES) in the White Mountains of New Hampshire, USA, was started in June 1963 by Gene E. Likens, F. Herbert Bormann, Noye M. Johnson, and Robert S. Pierce. Comprehensive, watershed-ecosystem mass balances of water and chemical elements have been done continuously until the present time. These long-term, integrated and continuous records of precipitation and streamwater amounts and their chemical composition from the Hubbard Brook Experimental Forest (HBEF) may be the longest in the world (Likens 2013, Holmes and Likens 2016). Long-term watershed and plot-scale studies of biotic, chemical, hydrologic, physical, and geologic conditions and their interactions have contributed to the overall ecological understanding of this complex ecosystem (see review in Holmes and Likens 2016).

Watershed-scale experimentation (e.g. deforestation, Watershed 2; forest strip cutting, Watershed 4; wholetree harvest, Watershed 5; base cation replenishment, Watershed 1) have revealed ecosystem processes at the landscape scale (figures 1 and 2; see Holmes and Likens 2016 for details).

\section{Biodiversity}

Major declines in bird, salamander, and insect populations have been observed. Bird abundance declined $\sim 55 \%$ from 1969 to 2000 with a small gradual increase recently (figure 3 ). Not all species declined, some remained about the same (red-eyed vireo, Vireo olivaceus), whereas others (black-throated green warbler, Setophaga virens) actually increased during this period (Holmes and Likens 2016). Terrestrial salamanders (northern red-backed, Plethodon cinereus) declined $74 \%$ since 1970) Holmes and Likens 2016, p. 65) and coleopteran beetles (Staphylinidae) declined markedly during the study (some beetles decreased by as much as $~ 83 \%$; the overall loss of taxa was $~ 39 \%$ (Harris et al. 2019). A strong relationship was found between average winter snow depth and number of beetles captured in the following summer, suggesting an effect of climate warming on beetle population size through direct mortality from the lack of an insulating snow cover (Harris et al. 2019).

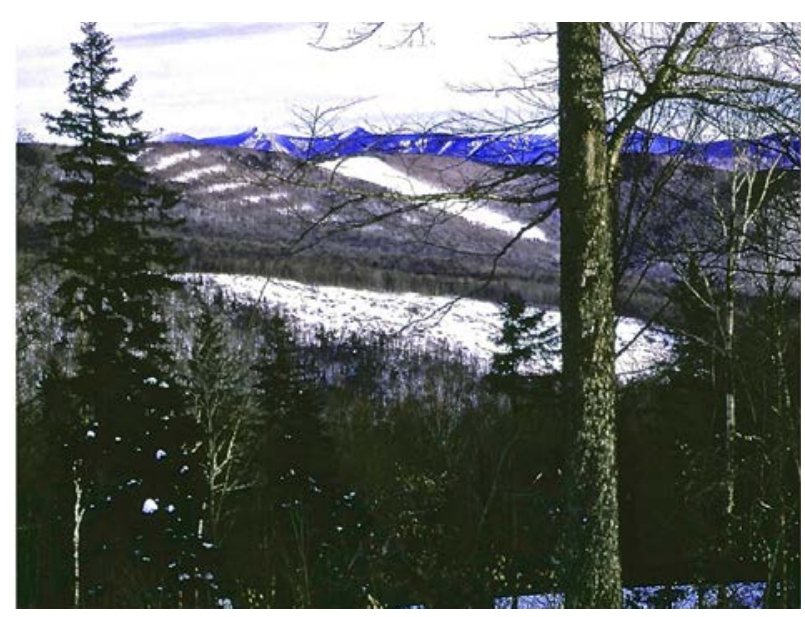

Fig. 1: View of experimentally manipulated watershed-ecosystems in the Hubbard Brook Valley (Photo by: G.E. Likens). 


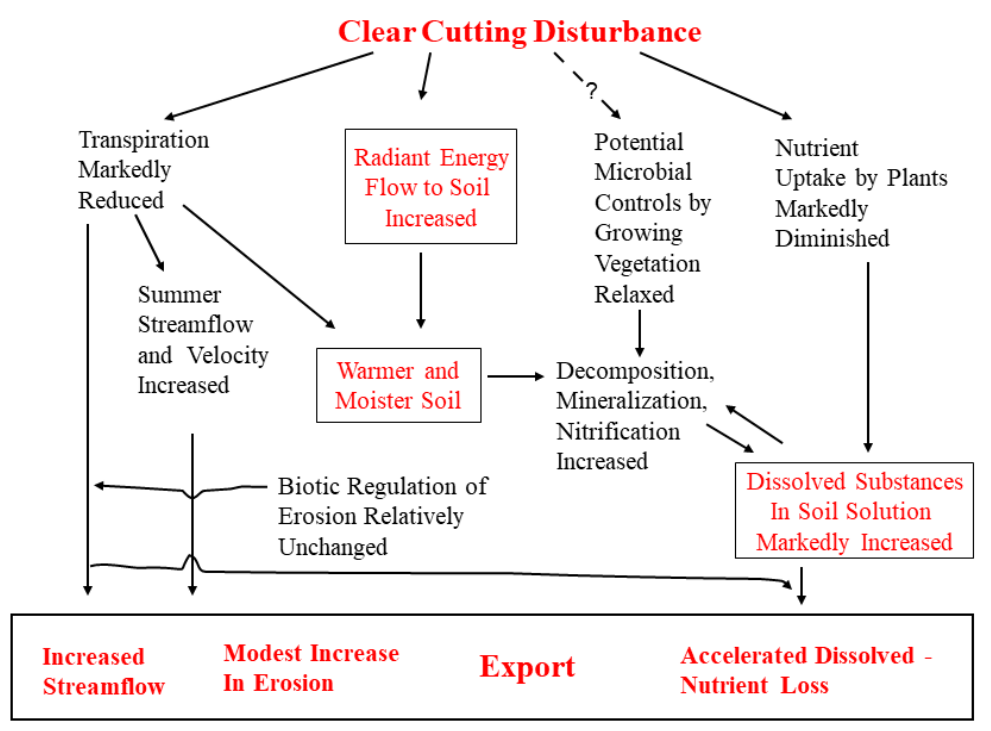

Fig. 2: Effects of major forest disturbance, such as deforestation or clearcutting, on water and nutrient dynamics of a northern hardwood forest ecosystem (modified from Bormann and Likens 1979; from Holmes and Likens 2016).

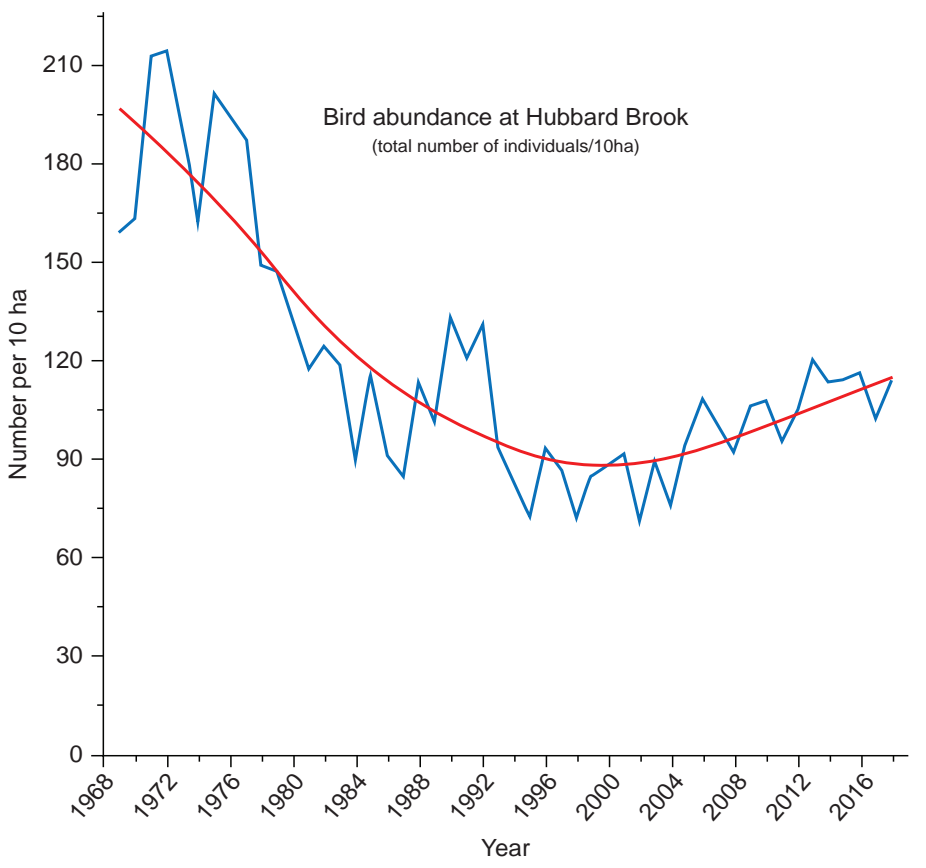

Fig. 3: Total bird abundance at Hubbard Brook Experimental Forest (modified and updated from Holmes 2007, Holmes and Likens 2016 and R. T. Holmes, personal communication). 


\section{Acid Rain}

The first sample of rain collected at the Hubbard Brook Experimental Forest was $\sim 100$ times more acidic than we thought it ought to be, but we really didn't know what it ought to be because there were no data available for comparison (figure 4). The $\mathrm{pH}$ of precipitation during the first complete water year (1964-65) was pH 4.12 (see Likens et al. 1972, Holmes and Likens 2016). This shocking discovery raised many important questions, e.g.:

- Was this acidity unusual?

- Was it unique to the White Mountains?

- How long had it been that way?

- Where did the acidity come from?

- What was the environmental impact?

Subsequent scientific research by many scientists in various locations showed that the major pollutants $\left(\mathrm{SO}_{2}\right.$ and $\left.\mathrm{NO}_{\mathrm{x}}\right)$ were generated from combustion of coal and oil and were emitted primarily from large power plants in the Midwestern U.S.; pollutants were converted to the strong acids, sulfuric and nitric, in the atmosphere and transported eastward by prevailing winds; hence acid rain was widespread in eastern North America and had serious impact on aquatic and terrestrial ecosystems (Holmes and Likens 2016).

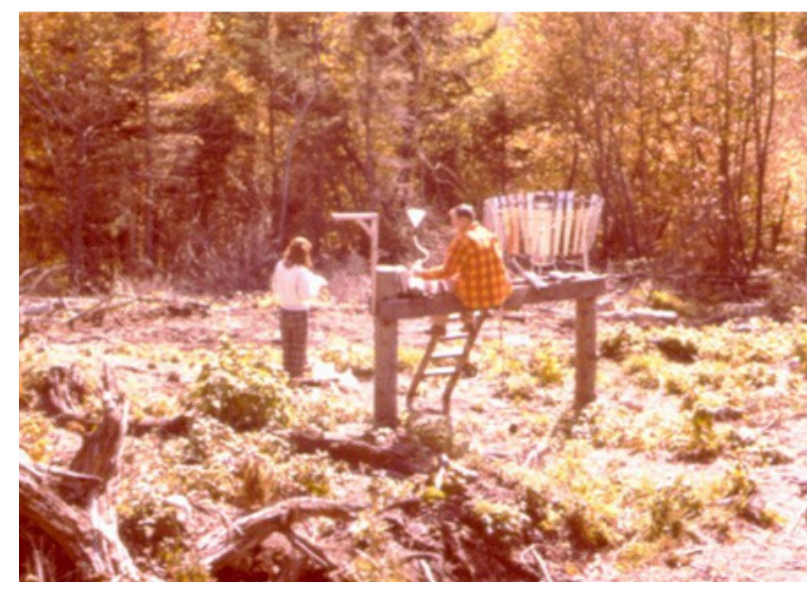

Fig. 4: Discovery of acid rain at Hubbard Brook in 1963 (from Holmes and Likens 2016).

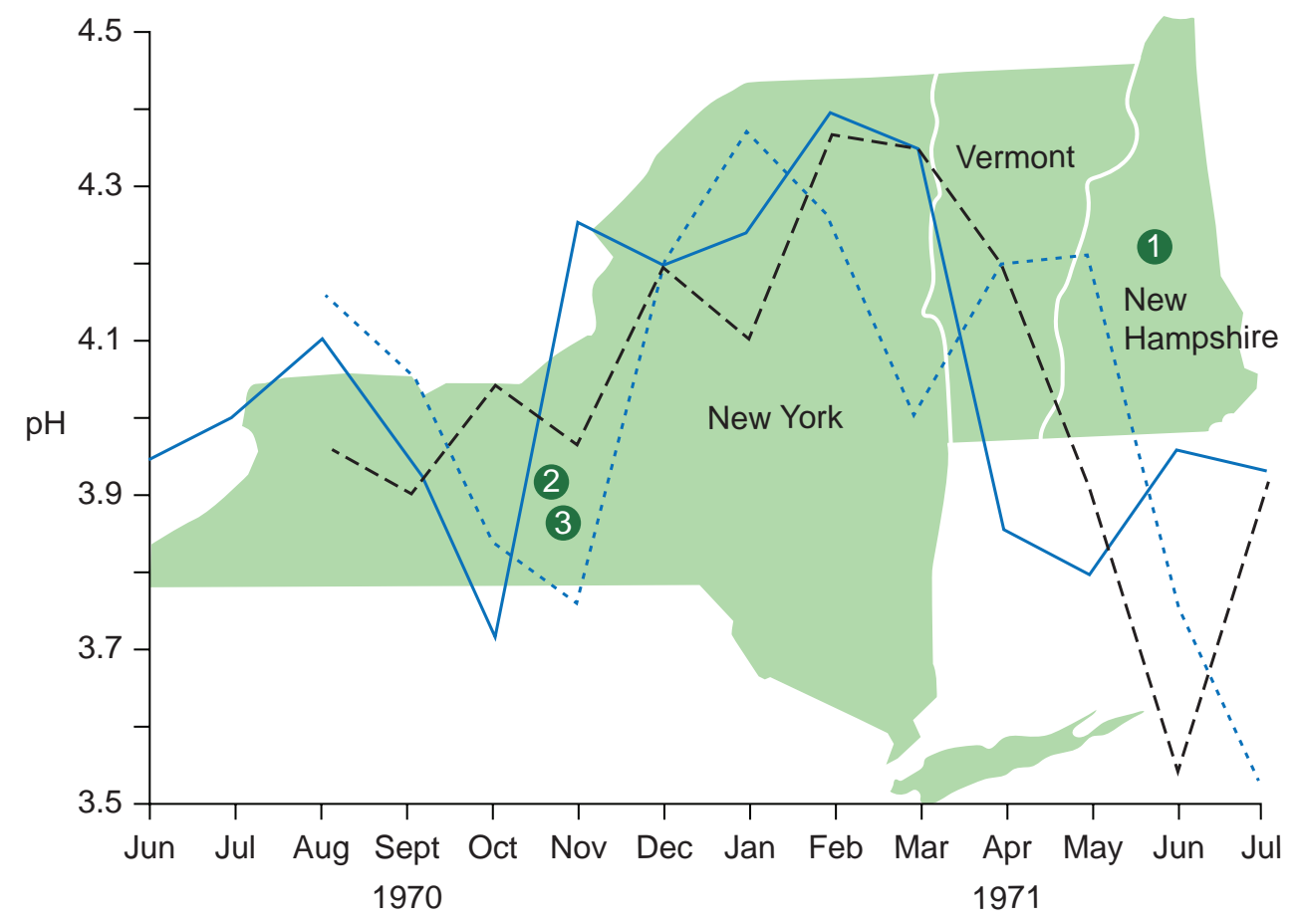

Fig. 5: pH of rain and snow at Hubbard Brook ( 1 ; solid blue line) and Aurora Experimental Farm, NY (2; dotted blue line), and Ithaca Game Farm, NY (3; dashed black line) during 1970-71 (Likens 1989). 
Our first clue that this acidity was a regional problem came from results I obtained in the Finger Lakes region of New York State (Likens 1972). The $\mathrm{pH}$ of rain and snow there was very similar to what we were measuring at Hubbard Brook (figure 5) (Likens 1989). Sharply declining emissions of $\mathrm{SO}_{2}$ and $\mathrm{NO}_{\mathrm{x}}$, the precursors to the formation of acid rain, because of the 1970 and 1990 Clean Air Act Amendments (CAAA) are correlated with the marked drop in acidity of rain and snow at HBEF since the peak in the late 1960s/early 1970 . The acidity has declined by $\sim 80 \%$ since this peak and represents an extraordinarily rare environmental success story (figure 6).

There have been a number of environmental impacts from acid rain (Likens 2010, Holmes and Likens 2016). One of the most important and unsuspected, was the exchange and loss of base cations from the poorly buffered soil from inputs of acid rain (Likens et al. 1996).

We experimentally tested the effects of this loss $(\sim 840 \mathrm{~kg}$ calcium/ha), which had been depleted from soil pools at HBEF during 1940-1995, by adding back this calcium to an entire watershed-ecosystem. We experimentally added wollastonite $\left(\mathrm{CaSiO}_{3}\right)$ in October 1999 to Watershed 1 by helicopter (1189 kg Ca/ha added) (Holmes and Likens 2016). As a result, there was a significant recovery of aboveground livetree biomass and protection of red spruce (Picea rubens) trees (figure 7).

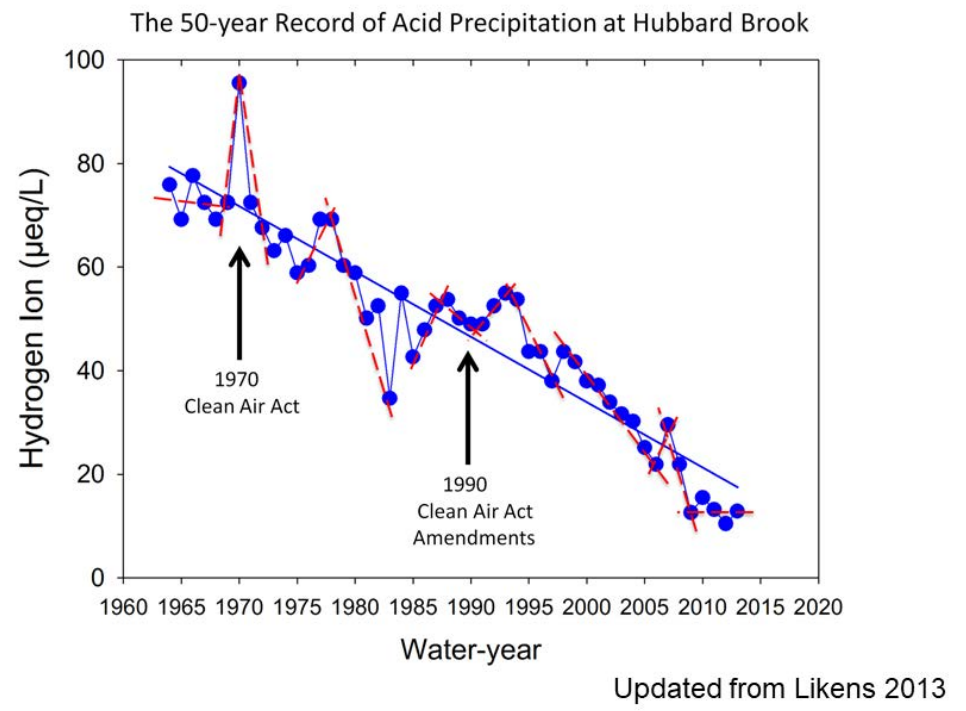

Fig. 6: The 50-year record of acid precipitation at Hubbard Brook (updated from Likens 2013; from Holmes and Likens 2016).

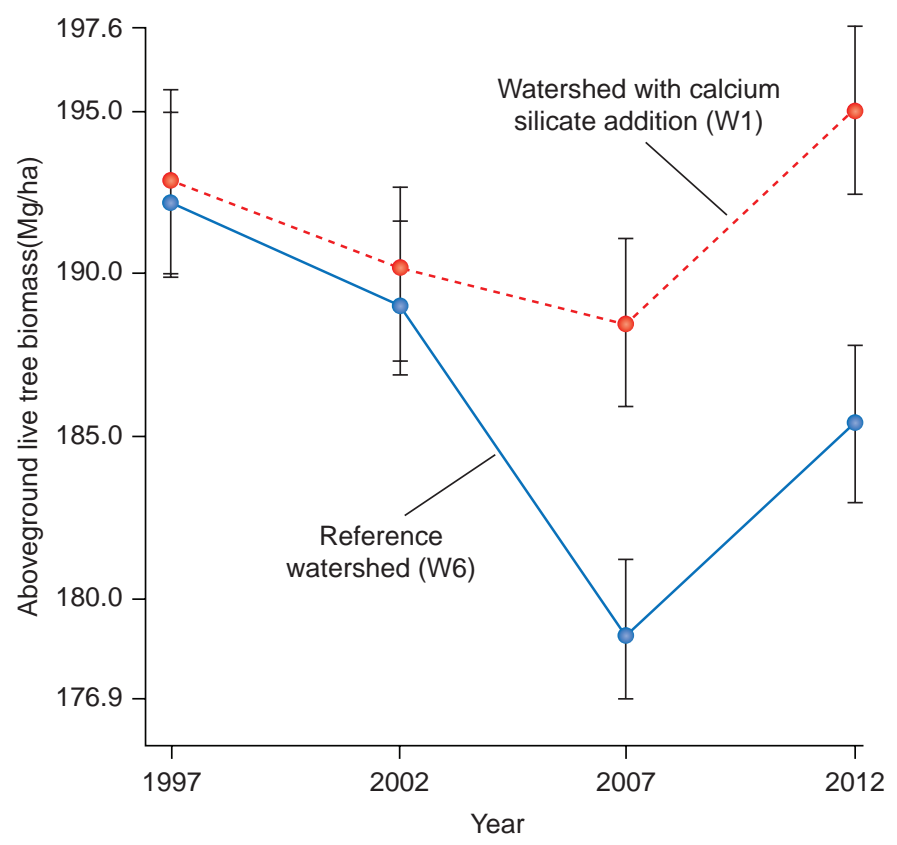

Fig. 7: Changes in aboveground live-tree biomass in Watershed 1 , treated with wollastonite, compared to a reference watershed-ecosystem (from Holmes and Likens 2016). 
It took 27 years from this remarkable discovery of acid rain in 1963 before political action was taken, i.e., the 1990 Clean Air Act Amendments, to deal with this major environmental problem in the United States.

\section{Climate Change}

Climate change is characterized by rapidly increasing and record high temperatures worldwide, increased weather variability, intensified storms, rising sea levels, acidification of the world's oceans, and major ecological changes. Long-term monitoring at Hubbard Brook has revealed many indicators of climate change.

- It is warmer and wetter (Likens 2013, Holmes and Likens 2016).

- Vegetation responses (biotic changes), e.g. vegetation breaks dormancy earlier in spring and leaves fall later in the autumn (Holmes and Likens 2016).

- Salamander loss occurs in streams because of increased variability in streamflow (Lowe et al. 2019).
The major lessons learned from more than 55 years of continuous research and monitoring are given in box 1 , and of course there are new problems to be investigated, such as the extreme dilution of precipitation and streamwater chemistry and its ecological impact (figure 8).

\begin{tabular}{|l|l|}
\hline Box 1: Major Lessons Learned In 56+ Years \\
\hline- & Discovery of Acid Rain in N. America \\
& (Increase in Acidity and Recovery) \\
- & Loss of Base Cations from Soil \\
& (Calcium - Limiting Nutrient) \\
- & Forest Stopped Growing \\
- & Policy Insights - The Ecosystem Approach vs Piecemeal \\
& Approaches Vital for Management \\
- & Effects of Disturbance on Biogeochemical Flux and \\
& Cycling - Management Relevance \\
- & Major declines in Bird, Salamander and Insect \\
& Populations \\
- & Many Indicators of Changing Climate \\
- & Extreme Dilution of Precipitation and Stream Water \\
\hline
\end{tabular}

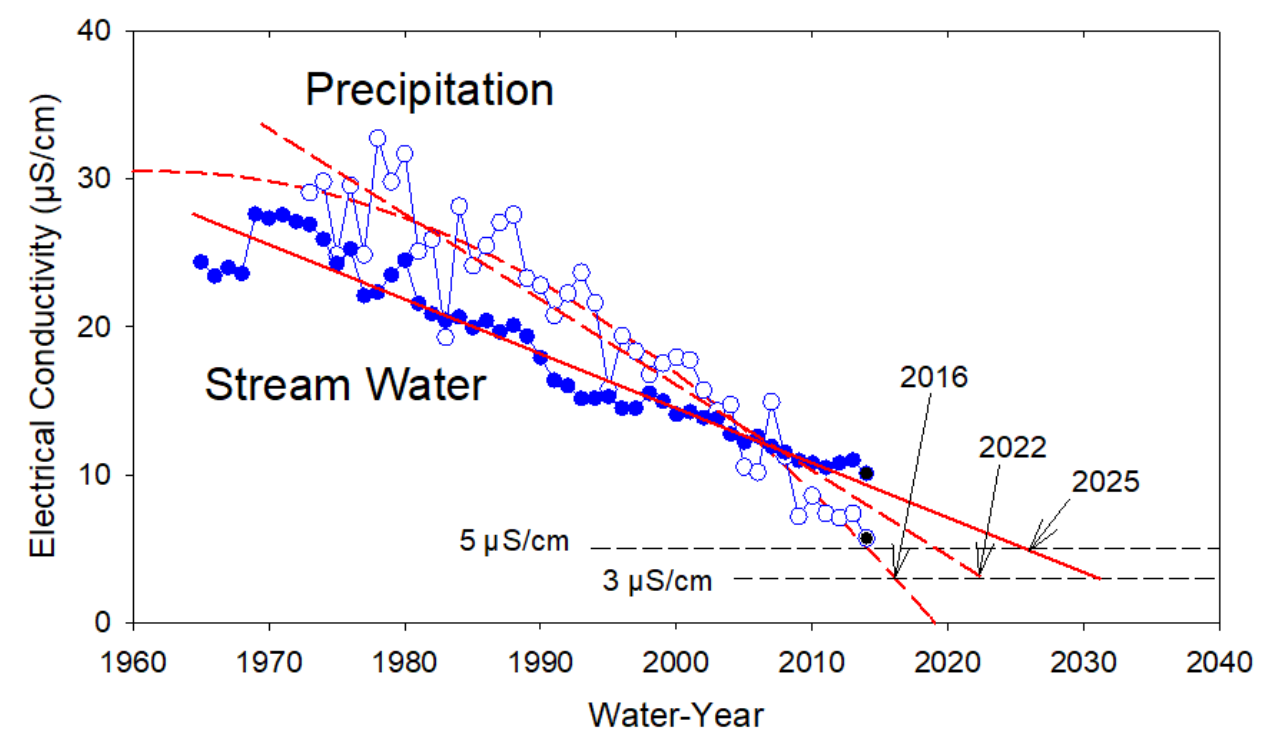

Fig. 8: Extreme dilution of precipitation and stream water in Watershed 6 of the Hubbard Brook Experimental Forest (updated from Likens and Buso 2012). 


\section{Acknowledgements}

The book by Holmes and Likens (2016) was used as a general reference source for these topics. Much additional information and literature can be found therein.

Appreciation to Matt Gillespie for help with manuscript preparation.

\section{References}

Bormann, F.H. and Likens, G.E. "Pattern and Process in a Forested Ecosystem”. New York: Springer, 1979.

Harris, J.E., Rodenhouse, N.L. and Holmes, R.T. "Decline in beetle abundance and diversity in an intact temperate forest linked to climate warming". Biological Conservation 240: 108219, 2019, http:// doi.org/10.1016/j.biocon.2019.108219

Holmes, R.T. "Understanding the population change in migratory songbirds: long-term and experimental studies of Neotropical migrants in breeding and wintering areas". Ibis 149 (Suppl. 2): $2-13,2007$

Holmes, R.T. and Likens, G.E. "Hubbard Brook: The Story of a Forest Ecosystem". New Haven: Yale University Press, 2016.

Likens, G.E., Bormann, F.H. and Johnson, N.M. “Acid rain". Environment 14(2): 33-40, 1972.

Likens, G.E. "The chemistry of precipitation in the central Finger Lakes Region". Water Resources and Marine Sciences Center Technical Report 50. Ithaca, New York: Cornell University, 1972.

Likens, G.E. "Some aspects of air pollution on terrestrial ecosystems and prospects for the future". Ambio 18(3): 172-178, 1989.

Likens, G.E., Driscoll, D.T. and Buso, D.C. "Longterm effects of acid rain: response and recovery of a forest ecosystem”. Science 272: 244-246, 1996.

Likens, G.E. "The role of science in decision making: does evidence-based science drive environmental policy?" Frontiers in Ecology and the Environment 8(6): e1-e8, 2010, https://doi.org/10.1890/090132
Likens, G.E. and Buso, D.C. 2012 "Dilution and the elusive baseline". Environmental Science \& Technology 46(8): 4382-4387, 2012, https://doi. org/10.1021/es3000189

Likens, G.E. " $3^{\text {rd }}$ Ed. Biogeochemistry of a Forested Ecosystem”. New York: Springer, 2013.

Lowe, W.H., Swartz, L.K., Addis, B.R. and Likens, G.E. "Hydrologic variability decreases survival through metamorphosis in a stream salamander". Proceedings of the National Academy of Sciences of the United States of America 116(39): 19563-19570, 2019, https://doi.org/10.1073/ pnas. 1908057116 
Global Use of Natural Resources:

Are we Heading for a New Sociometabolic Regime?

\author{
MARINA FISCHER-KowALSKI
}

Social metabolism describes the use of natural resources to produce and maintain society's biophysical structures: its human population, its animal population, and its man-made infrastructures.

The theory delivers:

- A historical perspective: the distinction between socio-metabolic regimes with characteristic resource profiles and system dynamics.

- It allows to link socioeconomic activity to ecosystem processes and ensuing sustainability problems.

In the following narrative (figure 1), we describe what we see as grand socio-metabolic regimes in human history, briefly sketch their key characteristics, and try to identify where we stand now.

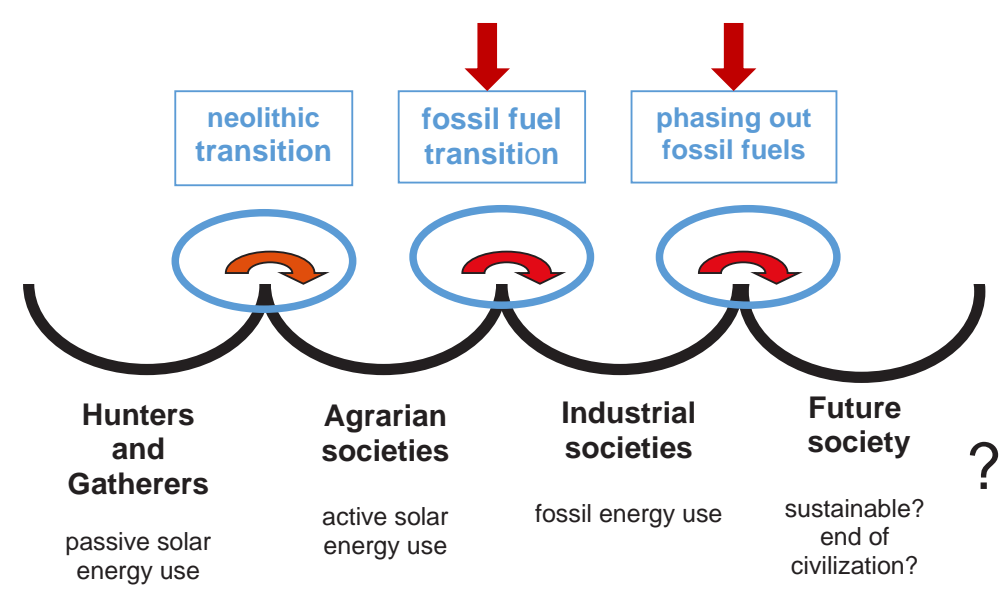

Fig. 1: Socio-metabolic regimes in human history, and their energy base (after: Fischer-Kowalski et al. 2014).

\section{Distinguishing Sociometabolic Regimes}

The human history as hunters and gatherers reaches far back, and in terms of their energy use they were not much distinct from other primates: they harvested the products of current photosynthesis wherever they could use them ("passive solar energy use"). In one important respect, though, they differed: they tamed fire to prepare their meals. This had essential consequences: they could digest a broader spectrum of food, and they saved on energy in its digestion (Wrangham 2009). What may have been even more important: Assembling around the fire for meals allowed them to develop a novel means of communication: spoken language, the starting point for evolving unique social complexity (Harari 2018).

The neolithic transition, then, led to agrarian societies that may be characterized by active solar energy use insofar, as they colonize the land to grow the food they want. In consequence, there is widespread deforestation, and for reasons explained below, a faster growth of the human population, and the emergence of cities. The latter allowed us to distinguish the common estimates of the global human population by their sociometabolic regime (see figure 2; mainly based upon Klein Goldewijk 2010). According to this estimate, there have been about 200 million people globally at $1 \mathrm{AD}$, equally divided between hunters \& gatherers and agrarian populations. 


\section{The Dynamics of the Agrarian Sociometabolic Regime}

Energetically, the agrarian regime can be characterized in the following way:

- the principal source of energy is land, more precisely, the products of photosynthesis from land.

- The principal source of mechanical work is human labor.

- How much energy the land has to offer depends on a number of natural conditions, but also critically on the human labor invested in this land. There is a land-labor-constraint of energy in the agrarian regime.

By the beginning of the $21^{\text {st }}$ century, about half of the world population is still living mostly in ways of the agrarian regime (see figure 2 ).

As agriculture and agrarian systems evolve, more energy is harnessed by taking ever more land under cultivation. More food can be extracted per unit land; thus, population density can increase. But this comes at the expense of a substantial human labor input. Human labor power and its biological reproduction requires most of the energy harvested. The EROI (or EROEI; Hall 1986) of agro-ecosystems is very low. Thus, in agrarian societies, $90-98 \%$ of the people have to work the land to provide for food and other needs of the population. The surplus that can be used by non-farmers (landlords, religious leaders, urban citizens, kings, administrators, armies...) is very small.

What is the socio-ecological dynamics within the agrarian regime? We can look both at the bottom-up and the top-down dynamics. The bottom-up dynamics can be described as follows:
- The people working the land develop better tools and techniques, better breeds, better storage...

- In the longer term, these efforts lead to a higher return from land at the expense of investing more labor (Boserup 1965, Ringhofer et al. 2014). This does hardly improve the EROI but raises working hours per unit land.

- Key response is high fertility: children can work while needing less food, often die before adolescence, and surviving they share in the workload of their aging parents.

- Over time, this process results in increasing the population and the workload per capita - a vicious cycle.

The top-down dynamics derives from the fact that, given the energy base of the system is land, rulers seek territorial expansion to become more powerful and rich (or to prevent their neighbors from that). This results in continuous warfare over territories, and colonialism.

\section{The Transition from the Agrarian to the Industrial Regime}

The transition out of the agrarian regime has the following preconditions:

- A new energy source with a higher EROI than biomass: fossil fuels. Peat, coal, oil and gas, in principle, free part of human labor power from food production.

- An institutional liberation of people from personal dependence on land and landlords (servanthood, slavery...), to be able to use their labor power on other activities, in cities.
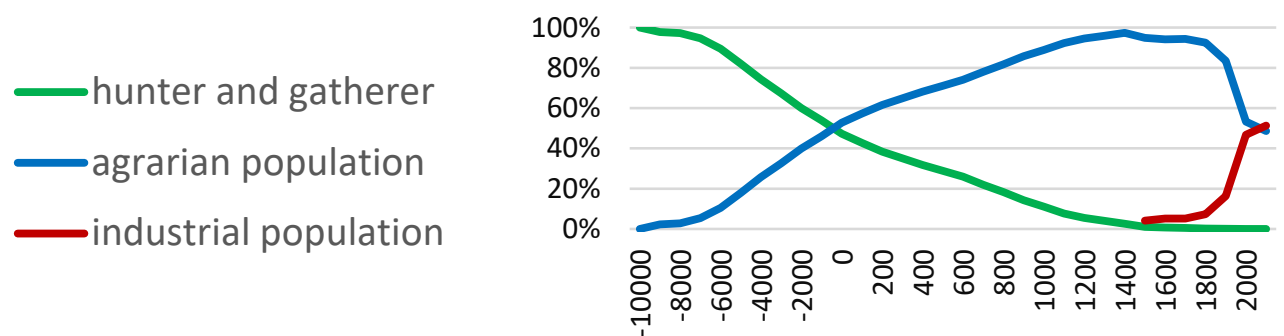

Fig. 2: Shares of the global human population 10000 BC-2010 AD by sociometabolic regime (Source: FischerKowalski et al. 2014). 
- A re-investment of surplus into infrastructure, further production and technological development (in other words, entrepreneurial activity), and not primarily into elite consumption, or warfare.

Such a transition required not only the access to deposits of fossil fuels, but also socio-political, economic, cultural and technological change, and it ran against the interests of feudal/colonial landlords. In contrast to mainstream thinking (Grübler 1998), the economic rise of England and The Netherlands, based upon fossil fuels (coal and peat) much preceded the major technological breakthroughs like the steam engine and railroads, and was based upon urban manufacture by workers enabled to heat their homes and cook by cheap energy carriers (figure 3 ).

In the very early phase of fossil fuel adoption, sociopolitical change was often achieved by social revolutions. "Freedom, equality, brotherliness" (France 1789), "terminating colonial rule" (Mexiko 1910, Vietnam 1968), "Socialism" (Russia 1917, China 1949) were the codes for a political departure from the agrarian regime and the take off of the industrial regime. These revolutions were costly and usually did not directly achieve their policy goals - but in the longer run, they led to capitalism, human welfare, democracy and human rights.

According to our analysis of the take off phase of fossil fuel use of 68 countries across the world and across the past five centuries, we could statistically show a high probability that revolutions happened during the very early phase of fossil fuel adoption (namely between 0,5 and 7,7 GJ fossil fuels per capita) (Fischer-Kowalski et al. 2019). European countries, for comparison, use currently around $200 \mathrm{GJ} /$ cap.

\section{A next Major Transition Ahead?}

While one might say that currently the industrial regime, in economic and military respects, dominates the world, actually only about half the global population spends its lives under this regime (see figure 2). Using the fossil fuel based transition markers, we can classify the countries of the world empirically in the following way:

- "Energy underdogs" = countries that had still been in their take-off phase (less than 8,0 GJ/cap; 1970-2015) to fossil fuels (and thus are largely "agrarian") $=42 \%$ of world population (3.1 bio).

- Countries maturing to fossil fuel use, i.e. using more than $8 \mathrm{GJ}_{\mathrm{FF}} /$ cap but less than $50 \mathrm{GJ}_{\mathrm{FF}}$ /cap in the period 1970-2015. They are accelerating or "transitioning" $=34 \%$ of world population (2.5 bio).

- Countries that have completed their energy transition, i.e. used $50 \mathrm{GJ}_{\mathrm{FF}} / \mathrm{cap}$ or more during the entire period 1970-2015. They are the "industrial cheerleaders" $=21 \%$ of world population (1.5 bio).

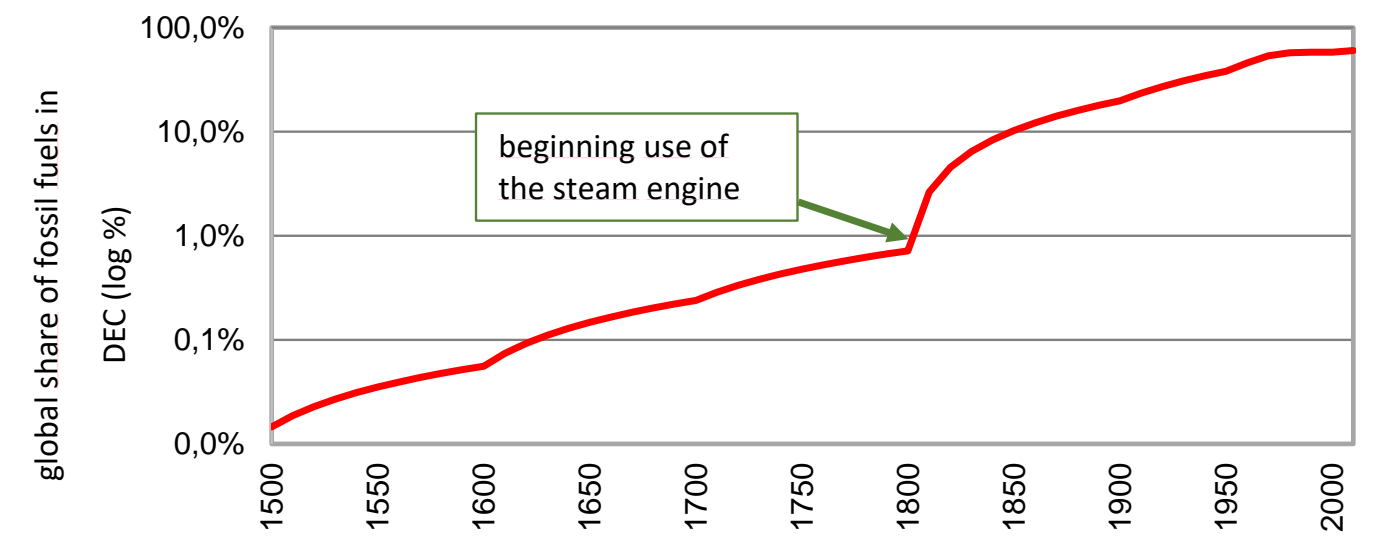

Fig. 3: The global share of fossil fuels in Domestic Energy Consumption (DEC) from 1500-2010 AD (Source: Fischer-Kowalski et al. 2014). 
As we can see in figure 4, countries within the "maturing" group have substantially increased their fossil fuel use per capita in the period observed, while the "industrial cheerleaders" show a slight decrease. At the same time, the "energy underdogs" were hardly able to increase their per capita energy consumption. During the same period, as shown in figure 5, the "maturing" countries gained only moderately in income, while the "industrial cheerleaders", despite of their slight decline in fossil energy, have gained very much. The "energy underdogs" had hardly any income increase at all, even less so than in energy.

Thus, obviously (not a great surprise), the world economy is more complex than a sequence of sociometabolic regimes would suggest. Outsourcing of resource extraction and industrial production combined with international trade mostly benefit the industrial cheerleaders economically while allowing them to stabilize or even reduce their fossil fuel consumption.

Still, the key question remains: Are there indications of a next major transition? A transition that would allow to stabilize global warming, slow biodiversity loss and human pressure on the earth's ecosystems? Unfortunately, as far as the global use of natural resources is concerned, we cannot see an indication in this direction (figure 6).

As apparent in figure 6, human extraction of natural resources from the Earth, and the $\mathrm{CO}_{2}$ emissions that result mostly from the fossil energy used for this level of activity, show no sign of deceleration. On the contrary, since the turn to the $21^{\text {st }}$ century, they seem even to accelerate. Thus, the inevitable next transition could indeed be a very dangerous one.

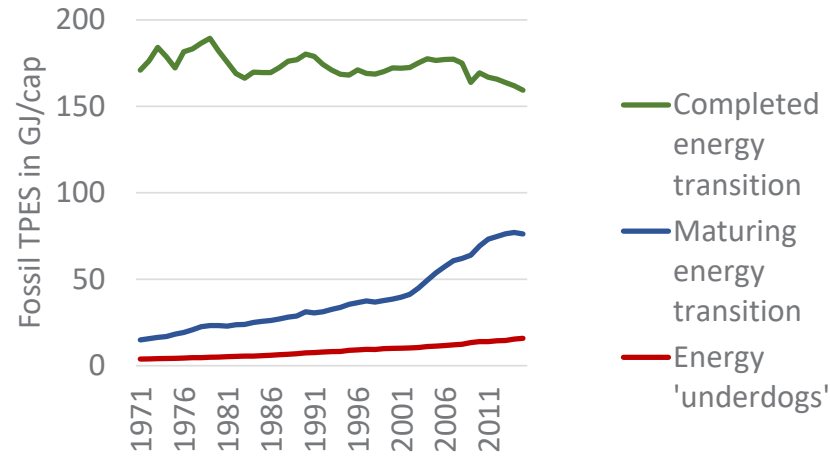

Fig. 4: Trajectories of fossil fuel use in the countries of the world 1971-2015 by their transition status from the agrarian to the industrial regime (Source: Schaffartzik \& Fischer-Kowalski 2018).

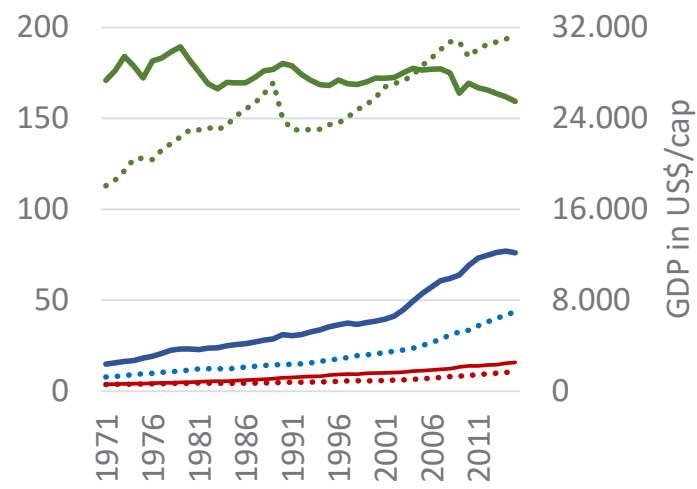

Fig. 5: Trajectories of fossil fuel use (left axis) and income (dotted lines, right axis) in the countries of the world 1971-2015 by their transition status from the agrarian to the industrial regime. Interpretation of the colours see figure 4 (Source: Schaffartzik \& FischerKowalski 2018).

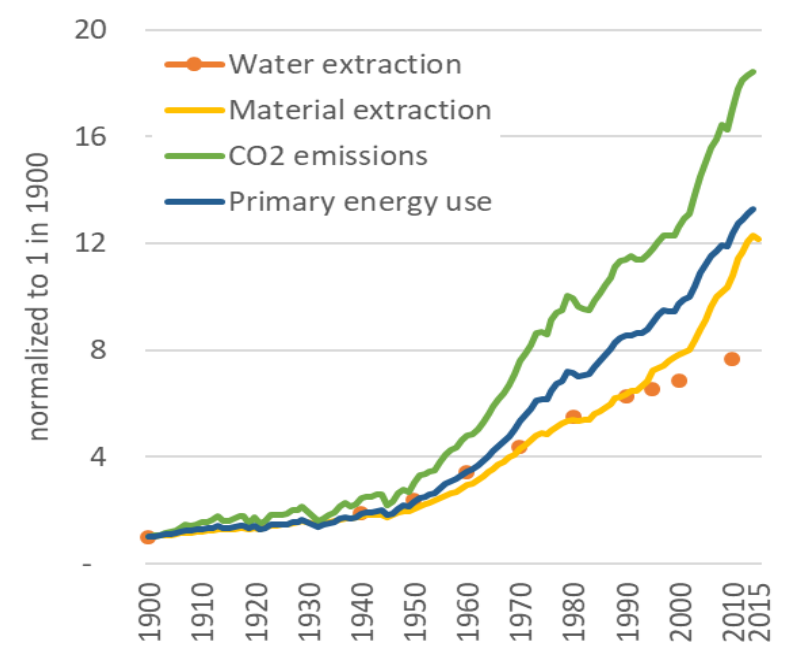

Fig. 6: Global resource extraction 1900-2015 (Source: Krausmann et al. 2018). 


\section{References}

Boserup, E. "The Conditions of Agricultural Growth. The Economics of Agrarian Change under Population Pressure." Chicago: Aldine/Earthscan, 1965.

Fischer-Kowalski, M., Rovenskaya, E., Krausmann, F., Pallua, I. and Mc Neill, J.R. "Energy Transitions and Social Revolutions." Technological Forecasting and Social Change 138: 69-77, 2019, https://doi. org/10.1016/j.techfore.2018.08.010.

Fischer-Kowalski, M., Krausmann, F. and Pallua, I. "A Sociometabolic Reading of the Anthropocene: Modes of Subsistence, Population Size and Human Impact on Earth". The Anthropocene Review 1, no. 1: 8-33, 2014, https://doi. org/10.1177/2053019613518033.

Grübler, A. "Technology and Global Change”. Cambridge: Cambridge University Press, 1998.

Hall, C., Cutler A.S., Cleveland, J. and Kaufmann, R. "Energy and Resource Quality: The Ecology of the Economic Process”. New York: Wiley, 1986.

Harari, Y.N. "Homo Deus: A Brief History Of Tomorrow”. New York: Harper Collins, 2018, ISBN No: 978-3-947851-09-6.

Klein Goldewijk, K., Beusen, A., and Janssen, P. "Long-Term Dynamic Modelling of Global Population and Built-up Area in a Spatially Explicit Way: HYDE 3.1." The Holocene 20, 565-573, 2010.

Krausmann, F., Lauk, C., Haas, W. and Wiedenhofer, D. "From Resource Extraction to Outflows of Wastes and Emissions: The Socioeconomic Metabolism of the Global Economy 1900-2015." Global Environmental Change 52, 131-140, 2018, https://doi.org/10.1016/j.gloenvcha.2018.07.003.

Ringhofer, L., Singh, S.J. and Fischer-Kowalski, M. "Beyond Boserup: The Role of Working Time in Agricultural Development”, In M. FischerKowalski, A. Reenberg, A. Schaffartzik and A. Mayer (eds) Ester Boserup's Legacy on Sustainability: Orientations for Contemporary Research 4: 117-138. Human-Environment Interactions. Dordrecht: Springer Netherlands, 2014, https:// doi.org/10.1007/978-94-017-8678-2.
Schaffartzik, A. and Fischer-Kowalski, A. "Latecomers to the Fossil Energy Transition, Frontrunners for Change? The Relevance of the Energy 'underdogs' for Sustainability Transformations." Sustainability (Switzerland) 10(8), 2018, https:// doi.org/10.3390/su10082650.

Wrangham, R. Catching Fire. How Cooking Made Us Human. New York: Basic Books, 2009. 


\title{
Trees at the Limit
}

\author{
CHRISTIAN KÖRNER
}

\section{Introduction}

All organisms reach a limit of their range somewhere on the planet, be it for abiotic, environmental reasons or for biotic interactions (competition, pathogens, lack of required mutualisms). In this essay I will refer to the abiotic range limits, often addressed as the boundaries of the fundamental niche of an organism. Apart from a lack of substrate (no soil), terrestrial plants may reach such limits for certain soil chemistry (salt, type of bedrock), too much (water logging) or insufficient water or too high or too low temperatures. Also abiotic disturbances may add to the niche determinants, such as wind exposure, avalanches, regular fire, erosion, etc. Once the causes of such range limits are deciphered, it might be possible to predict the potential occurrence of certain taxa, provided they can get to a target area (history of range expansion, corridors or barriers for migration). Here I will summarize what we know about the thermal and drought driven range limits of trees.

To start with, it is important to recall a few definitions and concepts. Trees represent a life form of plants (other life forms are shrubs, herbs, graminoids, annuals etc.). Species that belong to the life form tree (upright, single stemmed woody plants, at least as tall as a person but potentially much taller) undergo an ontogeny that starts from seedlings, moves to saplings, and arrives at increasingly taller individuals that are reproductive. The range limits may thus differ (1) for early and late developmental stages of a species and (2) among species, and finally reaches (3) the life form limit, beyond which no tree species can exist. In the following I will illustrate causes for adult tree species range limits and for the life form limit, the treeline. Compared to other life forms, trees have two handicaps when temperatures get low or when moisture becomes scarce. First, by their stature, they are intimately coupled to the freely circulating air, and second, they cannot hide and wait as many perennials with below ground survival-structures do (bulbs, rhizoms) when severe drought comes into play. Hence, whatever atmospheric challenges trees face, they are fully exposed to them.

\section{The Low Temperature Range Limits of Trees, the Treeline}

This is a global phenomenon. Alexander von Humboldt was probably the first to explicitly refer to the treeline as a biogeographic boundary between the montane forests and the naturally treeless alpine world (Körner and Spehn 2019). His famous illustrations capture the latitudinal shift in treeline elevation from sea level at the polar treeline to elevations of $4000 \mathrm{~m}$ or more near the equator (figure 1), reflecting the rise in temperature for a given elevation as one moves to low latitudes.

About 200 tree species are able to grow at the low temperature tree limit globally. No species can make a living beyond the treeline. Why are trees reaching a low temperature range limit, the treeline, with other life forms doing well at much higher elevations? What is the critical temperature? Which are the likely mechanisms that cause this abrupt change in life form?

Thanks to global climatic data bases, the possibility to locate trees on satellite images, and thanks to fully water proof miniature temperature loggers, it was possible to identify the nature of the minimum thermal 


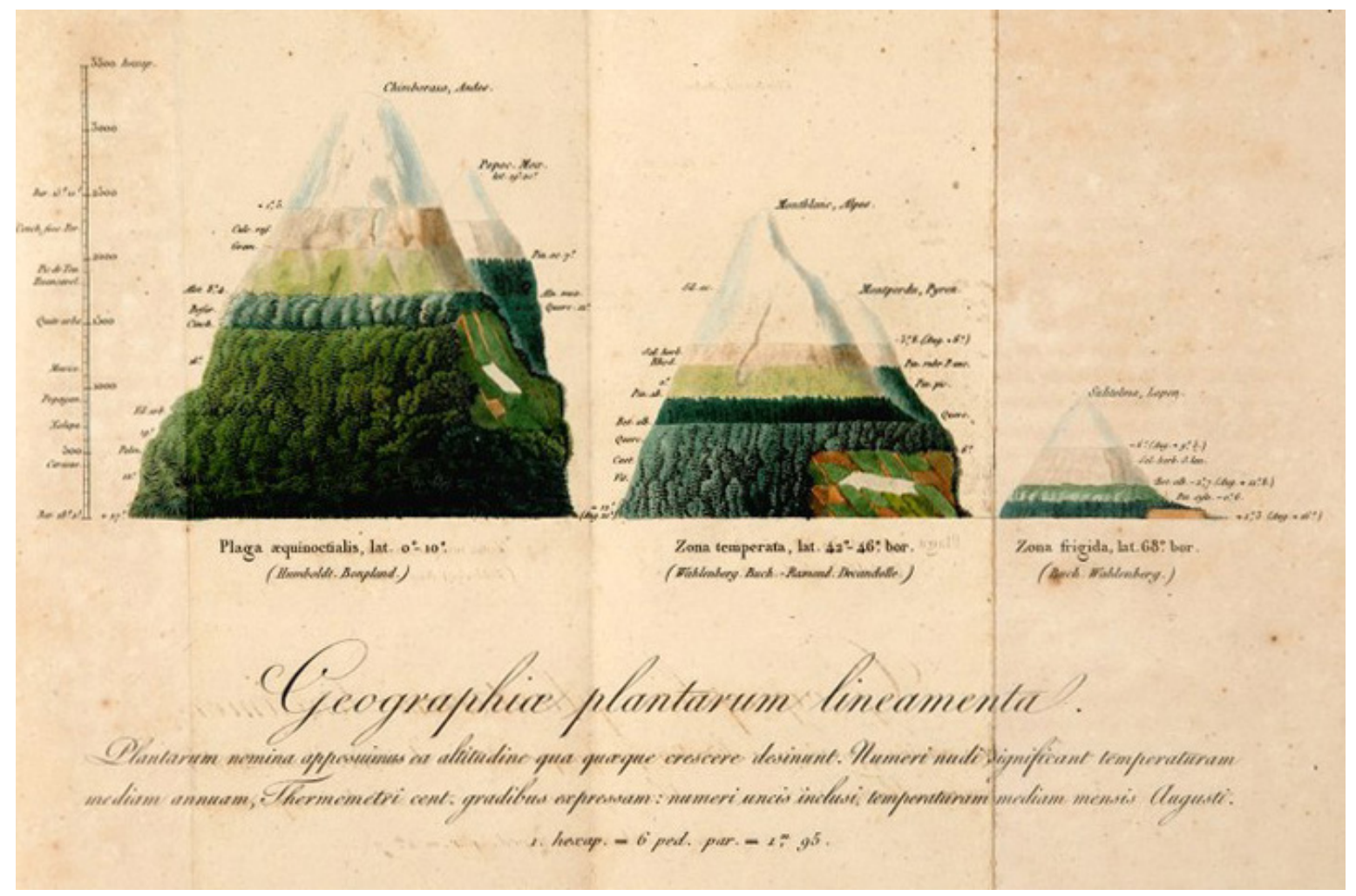

Fig. 1: The global treeline phenomenon as captured by A. v. Humboldt. His conceptual illustrations are the earliest to suggest isotherms (lines of equal mean temperature) connecting the mountains of the world. Source: Humboldt (1817), De distributione geographica plantarum secundum coeli temperiem et altitudinem montium, prolegomena. Paris: Libraria Graeco-Latino-Germanica (Voyage de Humboldt et Bonpland).

requirements for adapted trees to just survive: a length of the growing season of at least three months and a mean temperature during that period of approx. $6{ }^{\circ} \mathrm{C}$ (Körner and Paulsen 2004; Paulsen and Körner 2014). This treeline isotherm permits predicting the position of the treeline wherever drought does not prevent tree growth. The only regions where this predictive tool fails is where - for what ever reason - suitable treeline species are missing such as on Hawaii, in some Mediterranean areas or islands in general (Karger et al. 2019).

Trees are facing such a thermal limit at lines that look like the coastline of a water reservoir when viewed from an airplane, because they are tightly coupled to the temperature of the free atmosphere that cools with elevation by roughly $0.55 \mathrm{~K}$ per $100 \mathrm{~m}$. So the treeline mirrors the vertical decline in air temperature. In contrast, small stature plants such as shrubs, herbs and grasses profit from sun-driven heat accumulation near the ground. By their morphology, they decouple aerodynamically from the free atmosphere and 'engineer' their own microclimate, which thus, cannot be predicted from data collected from weather stations (Scherrer and Körner 2011).
The biological causes for the treeline at a seasonal mean temperature of $6^{\circ} \mathrm{C}$ are still not fully understood. However, it can be ruled out that freezing tolerance is decisive, given the many different climates at the treeline in the mountains of the world from Siberia to Kilimanjaro. Absolute minima of temperature are not associated with seasonal means in a predictive manner across the globe. Further, it can be ruled out that trees at treeline are carbon limited (limited by photosynthesis). Trees at treeline are packed with reserves globally. A most plausible explanation is the direct impact of low temperature on growing tissues. The cambial activity in trees, but also the activity of apical meristems in shoots and roots becomes extremely slow below $6{ }^{\circ} \mathrm{C}$ (figure 2). So it seems, the price paid by trees for being tall and being able to shade out neighbours, is their exposure to cool temperatures that directly constrain the building of new tissues and organs. These are basic constraints of plant growth for all cold adapted plants, but by their architecture, trees are so exposed to free air circulation, that they become hit first, explaining the tight coupling to a unique treeline isotherm. 
What is causing the low temperature tree limit?

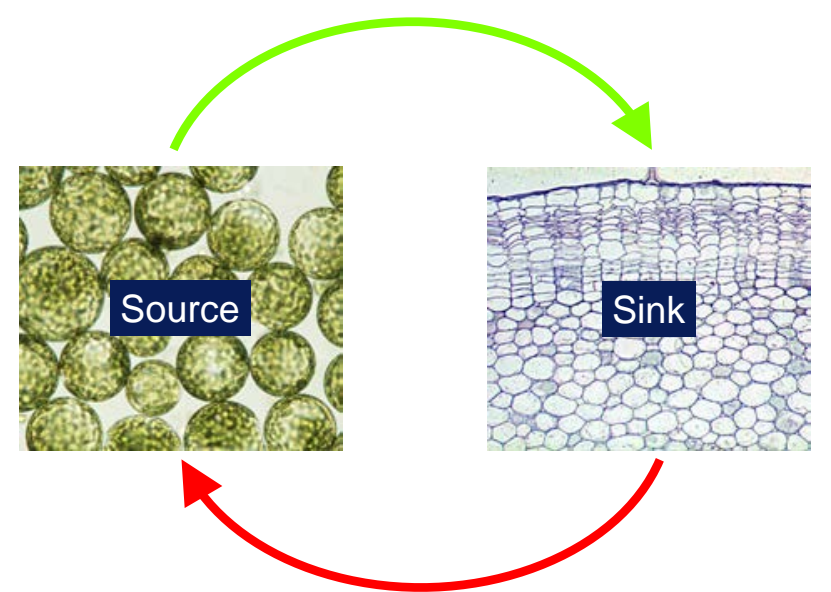

...you cannot decouple the two in the long run

over 5 years with 6 young academics for 7 European tree species: beech, oak, cherry, lime, hornbeam, maple, and rowan. For each species, we identified undisturbed extreme elevations in the Alps and high latitude limits in Scandinavia, measured right in the tree's canopy temperature extremes with c. 100 automatic sensors and linked their data to long term meteorological records to reconstruct the recurrence rates of extremes over the past 100 years. With this, the actual temperatures at the species specific range limit are well constrained.

The biological findings where the following: In no case did trees fail to reproduce at their range limit. Seeds matured at the range limit and were viable. Exploring the carbohydrate stores revealed no obvious carbon limitation either. Phenology of seasonal development differed among species, with some flushing early, some late. Growth rates as assessed by tree rings showed almost no decline until very close to the range limit, but right at the limit, there was still a reasonable growth rate with no missing annual growth rings. Ext-

\section{The Low Temperate Range Limits of Temperate Deciduous Tree Species}

Below the treeline, all tree species on earth reach their individual low temperature limit, the species specific range limit. For instance, apple trees cannot grow above $1400-1500 \mathrm{~m}$ in the Alps. In the tropics and subtropics, most palms cannot grow where frost occurs (Larcher 2003). All the important tree species of the European temperate deciduous forest have their specific range limit. One way of exploring this would be mapping occurrences, and drawing a boundary line and search for a best correlating environmental factor. Such statistical procedures have several shortcomings. Using mapped occurrence data cannot account for reasons other than the abiotic environment that control their range. Then many climatic signals are confounded, so it remains uncovered whether extremes or means matter. Finally, such statistics do not reveal the likely mechanisms that set the limit.

The efforts towards arriving at a functional explanation of range limits of species can become prohibitively complex. Thanks to a large grant by the European Research Commission, we could explore this question remely low winter temperatures and maximum freezing resistance in winter revealed no explanation of range limits. However, freezing tolerance immediately at and after bud break turned out to be a decisive factor across taxa. Trees were found to enter bud break in spring when their species specific freezing tolerance permitted, accounting for the statistical probability of the occurrence of critically low temperatures. In other words: buds opened when the dangerous period was over and that timing underwent species specific evolutionary selection. Species with a heritable low tolerance flush late, and very tolerant species flush early. Yet, species are not free to start their season so late that all risks are gone. In that case, the remaining season becomes too short to complete the species specific seasonal developmental cycle (wood maturation, fruit and seed maturation, hardy winter buds). So the range limit is defined by a finely tuned compromise between flushing as early as permitted by freezing tolerance and as late as permitted by the time required to mature before the onset of the next winter, with phenology tuning that compromise (for a summary see Körner et al. 2016). So, in the temperate zone, tree species ran- 
ge limits are largely defined by the tolerance to late freezing events in spring and the length of the remaining season as set by phenology.

\section{Trees at the Drought Limit}

As with temperature, drought can determinate season length, and affect plants gradually or by extreme events. While all three can set species as well as life form range limits, they often belong to the same syndrome. In the long run, any change in the water regime will change community composition and cause some species to become winners, while others become losers. Here I will illustrate cases in which long seasonal drought is combined with severe, endof-dry-season tree dehydration stress, that ultimately leads to the absence of trees, but in a far less regular way as is the case with low temperature, because of the patchy nature of soil depth and deep soil moisture stores. I will disregard cases where trees have ground water access or are confined to ravines or gorges in otherwise very dry regions. As a rule of thumb, an annual precipitation of less than $250 \mathrm{~mm}$ prevents tree existence in temperate climates, and the threshold my rise to $300 \mathrm{~mm}$ at lower latitude. Yet, it is not the annual sum but the temporal spacing of rain events that matters, because many small rain events may never re-charge the main root horizon, while a few heavy events do.

What is it that kills a tree when water becomes short? Ultimately it is the dehydration tolerance of its tissues. Most plant tissues die when they lost about half of their water content, but there is a wide tolerance spectrum. A more difficult issue is to find out why trees dehydrate and why species are affected differently in the field. Under good moisture supply, there is a capillary water continuum from soil water stores to the root surface, through the roots cortex into the xylem network that connects active root tips with the leaf mesophyll. Note, the xylem itself is built from dead cells that conduct water, but do not 'pull' water. As water evaporates from the wet cell surfaces in the interior of the leaf because leaf pores (stomata) are open and the atmosphere is not vapour saturated, these inelastic capillaries are pulled through the plant by leaf transpiration. The flow of water passes over resistors - some potentially very large and variable, others less variable and contributing little to the overall limitation of the hydraulic system.
The most variable and also most important resistors in the 'soil-plant-atmosphere-continuum' are the connection between the root and the water reservoirs in the soil matrix and between the sub-stomatal cavity in the leaf and the free atmosphere. The hydraulic system inside the plant is commonly of minor significance (highly efficient). When it gets dry, the soil resistance rises to a point beyond which trees cannot obtain sufficient moisture. Because of inevitably ongoing moisture losses to the atmosphere, the tree runs into severe water deficits that also cause tension in the xylem capillaries which may brake (embolize). The important point here is that this capillary collapse is one of the by-products of the inability of roots to acquire moisture, not the primary cause of tree dehydration. Once these capillaries broke, and thus, became relaxed, their water can be absorbed by surrounding parenchyma in the stem or in leaves, with the size of these stores important for survival.

Surviving severe drought, thus depends on three factors: (1) the root system's ability to reach deep soil moisture (figure 3), (2) the plants ability to minimize vapour losses after stomatal closure (figure 4), and (3) the size of the tree's water reserves by the time stomata close. Once roots fail to acquire moisture, the time to mortality is defined by the available moisture reserves in the tree that exceed the dehydration tolerance and the daily losses of water to the atmosphere. That time span can be a few days, a few weeks, or several months. Although these relationships are very obvious, research over the past decade was misdirected toward studies of the xylem's capacity to facilitate water flow. It is quite obvious that water flow in stems will approach almost zero after stomatal closure under severe drought, hence drought is the situation with the least demand in conductive capacity (Körner 2019).

In summary, trees are absent from places where regular or extreme drought exceeds the ability of a tree to control the above three components of the water regime when soils are dry. Shortage of water does not cause trees to fall short in photo-assimilates as is often assumed (except for extreme cases when drought exceeds a year). Also dying trees are not necessarily containing less carbohydrate reserves than healthy trees (Klein et al. 2014). The reason is that carbon demanding processes like structural growth and associated nutrient uptake are interrupted already at very mild drought, when stomata are still open and plants keep photosynthesizing beyond what can actually be used 
for growth (figure 2; Körner 2015). So carbohydrate reserves rise under drought and often reach a peak at the end of a dry period (Körner 2003). Trees at the drought limit do not starve but die from 'thirst'.

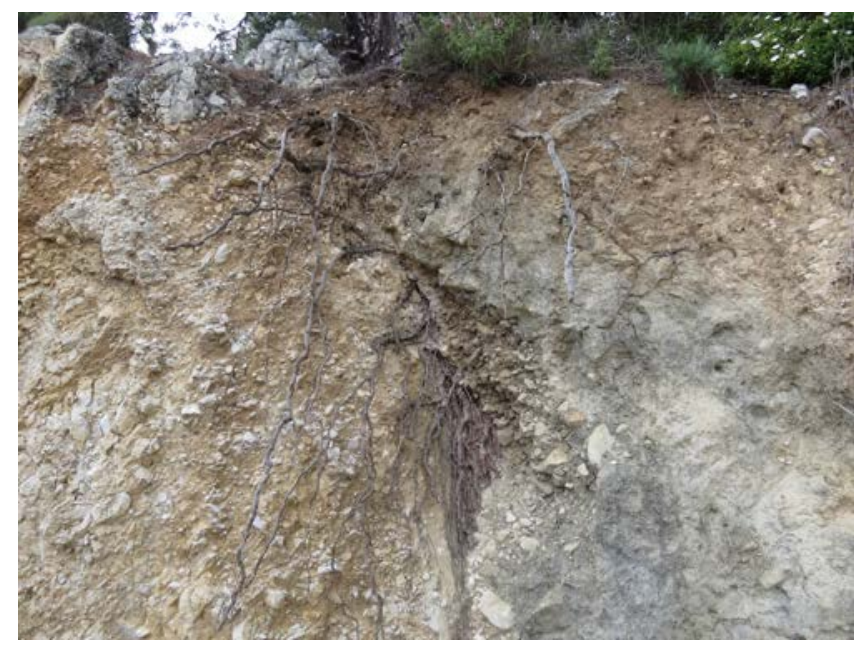

Fig. 3: Tree survival under drought depends on deep roots. Roots may reach significantly below $10 \mathrm{~m}$, often using fissures in rocks, a terrain inaccessible for soil moisture monitoring.

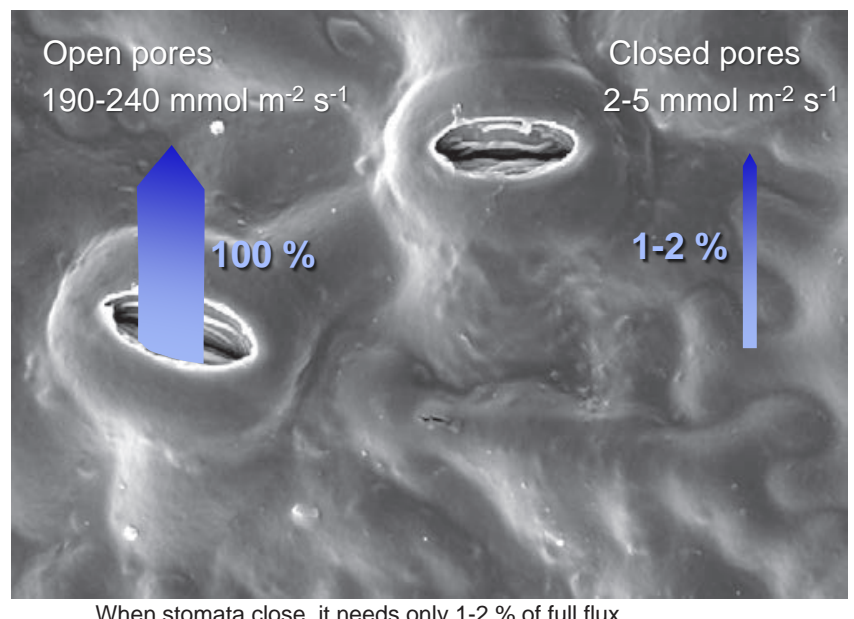

When stomata close, it needs only $1-2 \%$ of full flux

Fig. 4: Leaf stomata control the rate of water loss. When stomata close under drought stress, water consumption is reduced to very small quantities (water loss by the cuticula). Under such conditions the the hydraulic system (xylem) is greatly oversized even when parts are embolized, Thus 'hydraulic failure' cannot be a cause of tree mortality under drought (Körner 2019).

\section{References}

Karger, D.K., Kessler, M., Conrad, O., Weigelt, P., Kreft, H., König, C. and Zimmermann, N.E. "Why tree lines are lower on islands - Climatic and biogeographic effects hold the answer". Global Ecology and Biogeography 28: 839-850, 2019.

Klein, T., Hoch, G., Yakir, D. and Körner, C. "Drought stress, growth and nonstructural carbohydrate dynamics of pine trees in a semi-arid forest". Tree Physiology 34: 981-992, 2014.

Körner, C. "Carbon limitation in trees". Journal of Ecology 91: 4-17, 2003.

Körner, C. “Alpine Treelines”. Basel: Springer, 2012.

Körner, C. "Paradigm shift in plant growth control". Current Opinion in Plant Biology 25: 107-114, 2015.

Körner, C. "No need for pipes when the well is dry: a comment on hydraulic failure in trees". Tree Physiology, 39: 695-700, 2019.

Körner, C., Basler, D., Hoch, G., Kollas, C., Lenz, A., Randin, C.F., Vitasse, Y. and Zimmermann, N.E. "Where, why and how? Explaining the low-temperature range limits of temperate tree species". Journal of Ecology 104: 1076-1088, 2016.

Körner, C. and Paulsen, J. "A world-wide study of high altitude treeline temperatures". Journal of Biogeography 31: 713-732, 2004.

Körner, C. and Spehn, E.M. "A Humboldtian view of mountains". Science 365: 1061, 2019.

Larcher, W. "Physiological Ecology”. Berlin: Springer, 2003.

Paulsen, J., Körner, C. "A climate-based model to predict potential treeline position around the globe". Alpine Botany 124: 1-12, 2014.

Scherrer, D. and Körner, C. "Topographically controlled thermal-habitat differentiation buffers alpine plant diversity against climate warming". Journal of Biogeography 38: 406-416, 2011. 


\title{
Land Degradation and Rural Poverty in Africa
}

\author{
Phemo Karen Kgomotso
}

\section{Land Degradation - a Pernicious Problem}

Land degradation is a serious environmental problem that is challenging to address, and in its worst form, can be devastating to livelihoods directly dependent on land and natural resources, as well as to livestock and wildlife. As with other environmental problems, its impacts can be exacerbated by shocks and stressors such as drought and floods, and the long-term effects of climate change are projected to worsen the situation, particularly in marginal environments already affected by aridity and desertification.

The Intergovernmental Panel on Climate Change (IPCC) in its latest assessments defined land degradation 'as a negative trend in land condition, caused by direct or indirect human-induced processes including anthropogenic climate change, expressed as longterm reduction or loss of at least one of the following: biological productivity, ecological integrity or value to humans' (IPCC 2019).

The IPBES Assessment Report on Land Degradation and Restoration concludes that drylands are particularly susceptible to land degradation when one or more of the following features are present: low-productivity ecosystems; easily degradable soils; highly variable temperature and rainfall; and dense and rapidly growing populations of economically marginalized populations (IPBES 2018). These interrelated characteristics contribute to high rates of poverty and limit the capacity of populations to develop local mechanisms for coping with increasingly severe episodic or chronic deficits of food, water, energy and physical security.
As land is a key livelihood asset for the rural poor, when land loses productivity, its value is also lost, and those dependent on it are often faced with difficult choices, such as abandoning or investing more resources to restore it to an improved state, often at significant cost.

Despite the importance of land for human well-being, land degradation continues to increase worldwide due to several factors, including the expansion of crop and grazing lands into native vegetation, unsustainable agricultural and forestry practices, climate change, urban expansion, infrastructure development, and extractive industry. This is also illustrated in figure 1 below by the IPBES Assessment.

\section{Links between Land Degradation and Poverty in Africa}

Poverty and land degradation are inextricably linked. Poverty can act as a driver of land degradation when farmers, herders, and others who depend directly on land resources cannot wait for soils and vegetation to recover and resort to inappropriate land management (ELD Iniative \& UNEP 2015). Examples include eliminating fallow periods, farming on already poor soils in marginal areas, and keeping livestock in the same place too long. The picture from Eritrea (figure 2) illustrates a situation where large numbers of livestock are kept for long periods in already degraded grazing land. This land is also used to grow crops, and livestock are allowed in after harvest. 


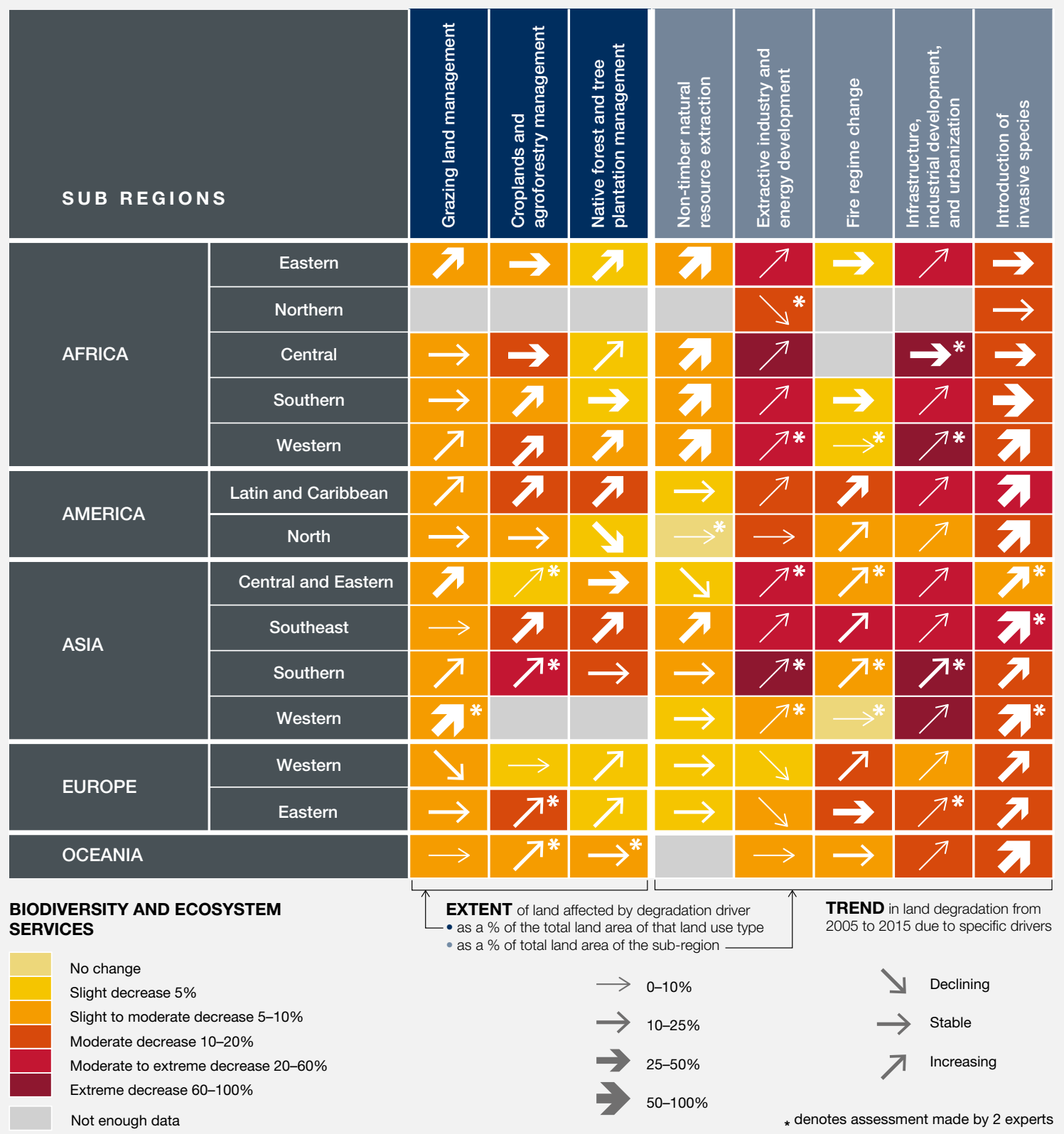

Fig. 1: Status, trend and extent of direct drivers of land degradation cross subregions globally. Source: IPBES, 2018, p. XXXI.

With low income levels and limited opportunities in more remote rural areas, it is not surprising that environmental degradation - as a result of reliance on fuelwood for cooking and heating or from using slashand-burn agriculture, for example - is common.
However, as incomes rise, environmental degradation tends to increase - as chemicals are overapplied due to increased availability without concomitant agricultural extension, or groundwater is overdrawn as a result of access to motor pumps (IFPRI 2019). 
Africa not only hosts the world's largest population on degraded rural drylands, but also more than half (61\%) of the rural population on degraded land in Africa reside on degraded rural drylands - particularly on rural hyper-arid drylands (46\%) and semiarid drylands (26\%) (UNCCD 2019). When faced with inability to produce food or make a living out of land, the result is often abandonment, and migration, from rural to urban centers, in some cases even further afield, for alternative livelihood opportunities. The demographic shift from rural to urban areas and the occupational shift from farming to other domains can have positive or negative implications for the environment. As agricultural labor becomes more scarce, labor-intensive approaches to resource conservation, such as terracing, and labor-intensive maintenance of irrigation become more difficult. The labor shortage is compounded in many areas where youth and men are likely to migrate or shift to nonagricultural enterprises, resulting in aging of the agricultural workforce and increased responsibilities for women. Many rural poor also often slip into further poverty, destitution and vulnerability when shocks hit. The IPBES Assessment estimates that by 2050,50 to 700 million people are projected to have migrated as a result of the combination of climate change and land degradation. Migrants can come into conflict with residents of the areas into which they move, especially if the destinations also have a fully used resource base or if they are already degraded.

A study by Mishra and Singh (2010) of the severe droughts in the Sahel that occurred during 1910s, 1940s, 1960s, 1970s and 1980s concluded that droughts caused huge socio-economic and environmental impacts in this semi-arid region, resulting in massive-scale migration, famine and environmental degradation (desertification), especially during the last two drought episodes. The study noted that growing demand for water, while sources are limited, and changes in spatio-temporal patterns of climate are aggravating the drought impacts in the world. As the UNCCD (2019) argues, physical declines in ecosystem services have a direct impact on the capacity of households to generate income due to reductions in labour, livestock and land productivity, as well as on the capacity of households to harvest products from nature for their own livelihoods. On the other hand, the constraints on productive activities in the agriculture sector (which includes crop, livestock and forestry) due to land degradation also indirectly affect household relative incomes through increases in food prices.

\section{Addressing Land Degradation: Sustainable Land Management and Restoration}

There is a political and economic dimension to land degradation. The assessment carried out by IPBES concludes that institutional, policy and governance responses to address land degradation are often reactive and fragmented, and fail to address the ultimate causes of degradation, with most policies directed at addressing land degradation being fragmented and targeting specific, visible drivers of degradation within specific sectors of the economy, in isolation from other drivers.

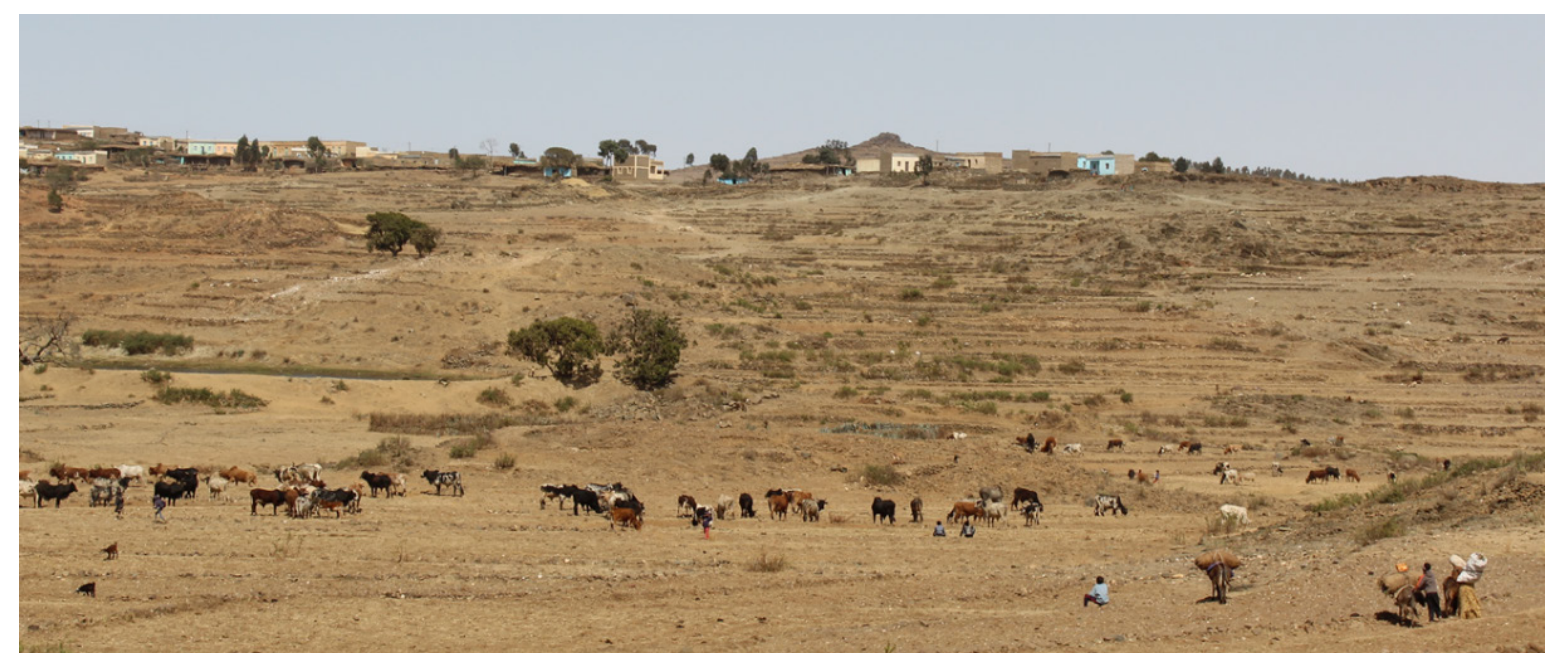

Fig. 2: Livestock in Eritrea (Photo credits: P.K. Kgomotso, 2015). 
We know that investing in restoring and rehabilitating degraded land would generate significant socio-economic benefits and ecosystem services - supporting agricultural livelihoods, increasing labour, livestock and land productivity, creating jobs and access to markets and stabilizing land tenure and food prices yet investments in sustainable land management and practices that seek to avoid, reduce and reverse land degradation are limited.

Often skills are lacking, and where they exist, investment costs are too prohibitive, or the enabling environment is limited or not conducive. Tenure insecurity for instance, is one of the factors that prevent investments in sustainable land management practices and approaches. Lack of tenure security, in any of its dimensions, implies that households or entrepreneurs face a risk of losing their property rights to a plot of land (and the associated income flows) at some point in the future ${ }^{1}$. Studies have shown that secure land rights and presence of land titles are often associated with greater long-term land investment and market transactions. Guaranteeing secure land tenure may help induce farmers to adopt long-term approaches to land management (figure 3). Countries with insecure land rights for those often struggle to over come the challenges of land degradation, as farmers and land users lack the confidence that investing in restoring land will directly benefit them over time. Technological, biophysical, socio-economic, financial and cultural barriers can limit the adoption of many land-based response options, as can uncertainty about benefits. Many sustainable land management practices are not widely adopted due to insecure land tenure, lack of access to resources and agricultural advisory services, insufficient and unequal private and public incentives, and lack of knowledge and practical experience.

The cyclic land redistribution system practiced in some parts of Eritrea have been shown to significantly discouraged land users and farmers from investing on a long-term basis in interventions that enhance the productivity of land. On the contrary, when the government introduced a new law to offer life-long usufruct of land to farmers - and piloted its implementation in 27 villages - there was a significant increase in investments in sustainable land management practices, and clear benefits for farmers, in terms of increased crop yields and an increase in the planting of trees for income generation purposes ${ }^{2}$.

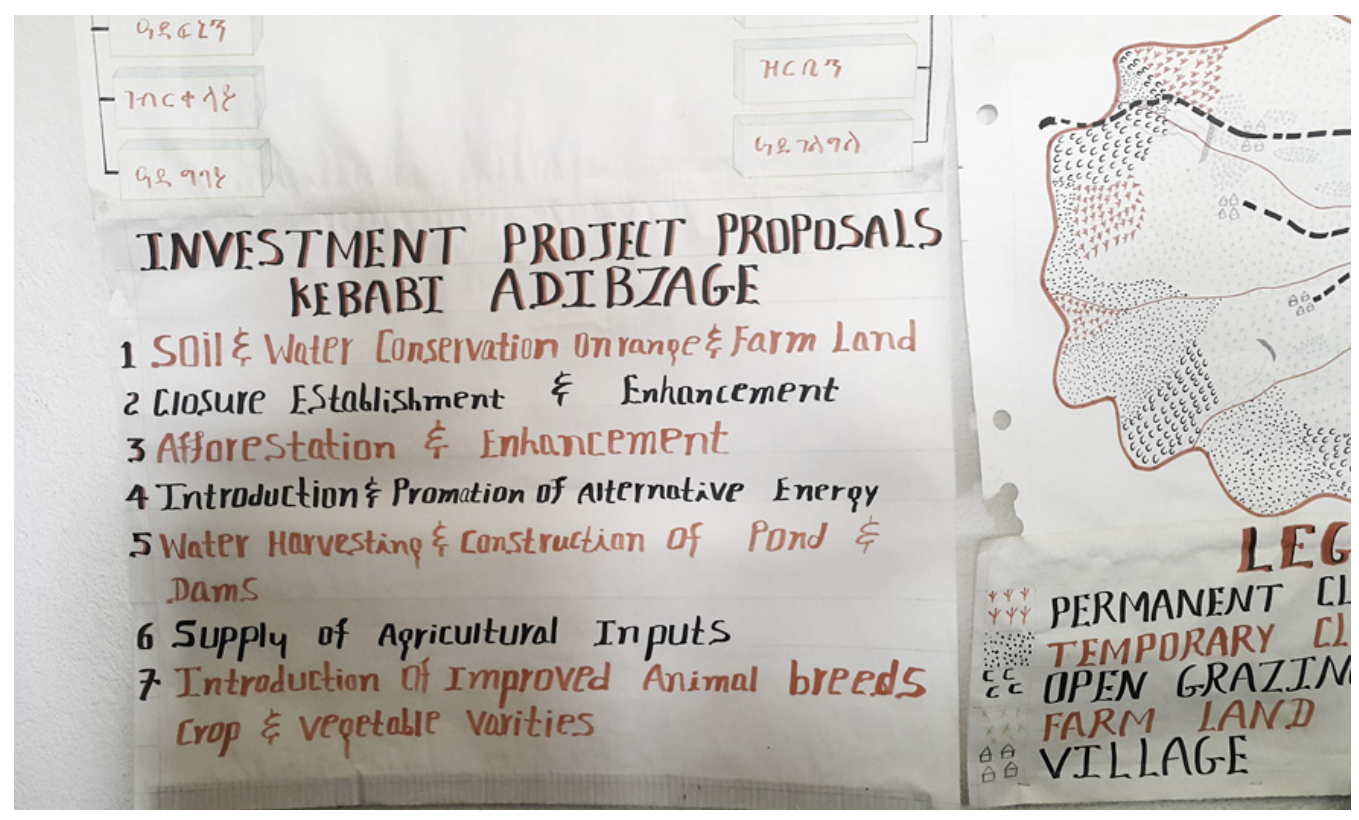

Fig. 3: Picture of a land use and management plan in an agricultural advisor's office in rural Eritrea. Source: P.K. Kgomotso.

1 World Bank. Property Rights to Land: https://www.worldbank.org/en/topic/land; accessed on June 24, 2020.

2 Based on independent end-of-project evaluation results of a GEF-financed, UNDP-supported 'Strategic Investment Program SLM Pilot Project', 2016. Available on demand. 


\section{A Restoration Hope?}

Restoration and rehabilitation may hold some hope for degraded environments and the people who inhabit them. Significant investments are required however, in creating an enabling environment to facilitate these investments, improving the skills of land users to adopt sustainable practices, as well as understanding the appropriate restoration and rehabilitation interventions for each context. Smith et al. (2020) assess the potential for 40 practices to address land challenges. They conclude that scientific efforts are needed to provide policy with robust, comprehensive, and transparent approaches, models, and tools for land use forecasting, incorporating multiple side effects, that is, biophysical, economic, and social, and that as long as policies and respective support from the scientific community remain sectoral, crosslinkages between sustainable land management and human well-being may be missed.

\section{References}

ELD Initiative \& UNEP “The Economics of Land Degradation in Africa: Benefits of Action Outweigh the Costs". Available from www.eld-initiative.org, 2015.

UNCCD "Land Degradation, Poverty and Inequality”. Bonn: UNCCD, 2019, http://catalogue.unccd. int/1230 UNCCD Poverty briefing note.pdf.

IPBES “The IPBES assessment report on land degradation and restoration". L. Montanarella, R. Scholes and A. Brainich (eds.), 2018. Bonn: Secretariat of the Intergovernmental Science-Policy Platform on Biodiversity and Ecosystem Services, Germany, ISBN No: 978-3-947851-09-6.

IPBES "Summary for policymakers of the assessment report on land degradation and restoration of the Intergovernmental Science-Policy Platform on Biodiversity and Ecosystem Services". R. Scholes, L. Montanarella, A. Brainich, N. Barger, B. ten Brink, M. Cantele, B. Erasmus, J. Fisher, T. Gardner, T.G. Holland, F. Kohler, J.S. Kotiaho, G. Von Maltitz, G. Nangendo, R. Pandit, J. Parrotta, M.D. Potts, S. Prince, M. Sankaran and L. Willemen (eds), 2018. Bonn: Intergovernmental SciencePolicy Plattform on Biodiversity and Ecosystem
Services (IPBES), https://doi.org/10.5281/zenodo.3237392.

IPCC “Special Report on Climate Change, Desertification, Land Degradation, Sustainable Land Management, Food Security, and Greenhouse gas fluxes in Terrestrial Ecosystems. Summary for Policymakers", 2019, https://www.ipcc.ch/site/assets/uploads/2019/08/4.-SPM Approved Microsite FINAL.pdf.

IFPRI “2019 Global Food Policy Report”. Washington, DC: International Food Policy Research Institute, 2019, https://doi.org/10.2499/9780896293502.

Mishra, A.K. and Singh, V.P. "A review of drought concepts”. Journal of Hydrology 391, 202-216, 2010, https://doi.org/10.1016/j.jhydrol.2010.07.012.

Smith, P., Calvin, K., Nkem, J. et al. "Which practices co-deliver food security, climate change mitigation and adaptation, and combat land degradation and desertification?" Global Change Biolology 2020, 26: 1532-1575, https://onlinelibrary.wiley. com/doi/epdf/10.1111/gcb.14878. 


\section{Author Biographies}

Marina Fischer-Kowalski is Professor emeritus and senior researcher at the Institute for Social Ecology, University for Natural Resources and Life Sciences, and lecturer for environmental sociology at the University of Vienna. With a Ph.D. in sociology from the University of Vienna, she was discontent with the social sciences' disregard for Nature as well as natural scientists' common disregard for society. In the late 1980ies, an interdisciplinary faculty (IFF) offered her the opportunity to found and for many years direct the Institute for Social Ecology in Vienna, Austria, and build up a team of social and natural scientists, with whom she developed the paradigm of social metabolism and colonization of nature. She served as President of the International Society for Industrial Ecology, Chair of the Scientific Advisory Board of the Potsdam Institute of Climate Impact Research (PIK), and President of the International Society for Ecological Economics. As expert member of UN's International Resource Panel, she introduced the socio-economic metabolism perspective there, became lead author to several of its publications, and established the metrics of social metabolism as common statistics at Eurostat. She is co-editor of the journal Anthropocene Review as well as INSEE, the Indian Journal for Ecological Economics, author of 19 books and about 200 book chapters and journal articles.

marina.fischer-kowalski@boku.ac.at

Gerhard Glatzel is Professor emeritus of Forest Ecology at BOKU University, Vienna. He studied Forestry at BOKU University and as a Fulbright Assistant at Utah State University in the US. His research focused on forest soil science, mineral nutrition, and water use of forests. He is well known for studies on the effects of atmospheric pollutant deposition on forest ecosystems of the Vienna Woods. Forests and land-use issues in tropical countries, in particular in highlands, were another area of interest. He initiated the Master Curriculum in Mountain Forestry, the first English language Master Curriculum at BOKU. A scientific hobby interest is the biology of mistletoes on a global scale. Advancing science and promoting science-based decision-making is a full-heartedly pursued mission. Gerhard Glatzel served in many national and international advisory boards, held positions in the Austrian Science Fund, as well as the European Science Foundation, and chaired several Commissions at the Austrian Academy of Sciences, amongst them the Commission for Development Studies, the Commission for Interdisciplinary Ecological Studies, and the Austrian IIASA Committee. He is a member of the Austrian Academy of Sciences and the German National Academy of Science and Engineering.

gerhard.glatzel@oeaw.ac.at
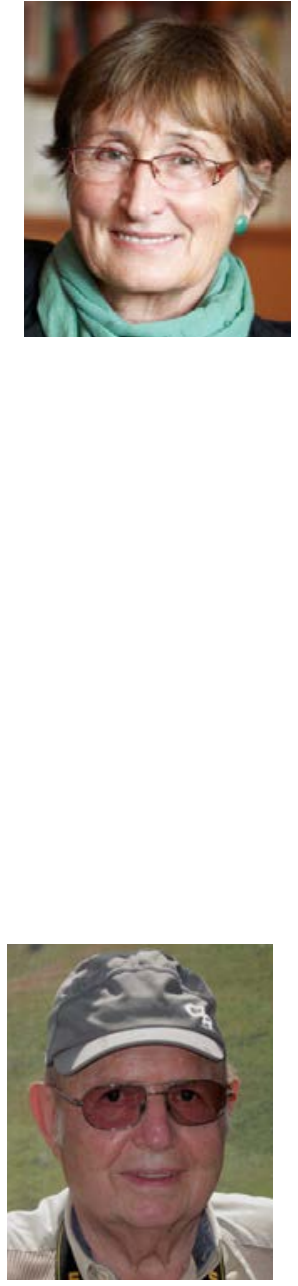
Phemo Kgomotso is a technical specialist on natural resource management with the United Nations Development Programme (UNDP). She is also the Regional Team Leader for the UNDP Nature, Climate and Energy team based in Addis Ababa and supporting government in the Africa region. Through her work, she supports countries to design policy and regulatory frameworks, sectoral approaches and community level solutions for addressing key environmental challenges such as biodiversity loss, land degradation and climate change and to promote sustainable natural resources management practices that build community and landscape resilience and contribute to increased productivity and poverty reduction and other SDGs. Phemo holds a Doctor of Philosophy degree from the Institute of Development Studies at the University of Sussex in the UK, where she studied the role of UN conventions and other similar frameworks in shaping national policy for governance of natural ecosystems and the outcomes of these policies on local human-environment interactions.

phemo.kgomotso@undp.org

Christian Körner is Professor emeritus of Botany at the University of Basel, Switzerland, where he held a full professorship from 1989 till 2014. He received his academic education at the University of Innsbruck, Austria. His work covers physiological ecology of plants, ecosystem ecology and biodiversity research. Christian Körner worked in all climatic zones, including the tropics and the Arctic. His mountain research explained high elevation plant life and the cause of arctic and alpine treelines (textbooks Alpine Plant Life and Alpine Treelines). Körner pioneered $\mathrm{CO}_{2}$ enrichment research in alpine ecosystems and in mature temperate trees and has published over 400 scientific publications. He is member of several Academies of Sciences, among other awards, has two honoris causa doctorates, and is a foreign honorary member of the American Ecological Society. He held positions in international research programs such as IGBP and Diversitas, and he founded and chaired the Global Mountain Biodiversity Assessment (GMBA). Currently, he is continuing alpine research in the Swiss Alps.

ch.koerner@unibas.ch
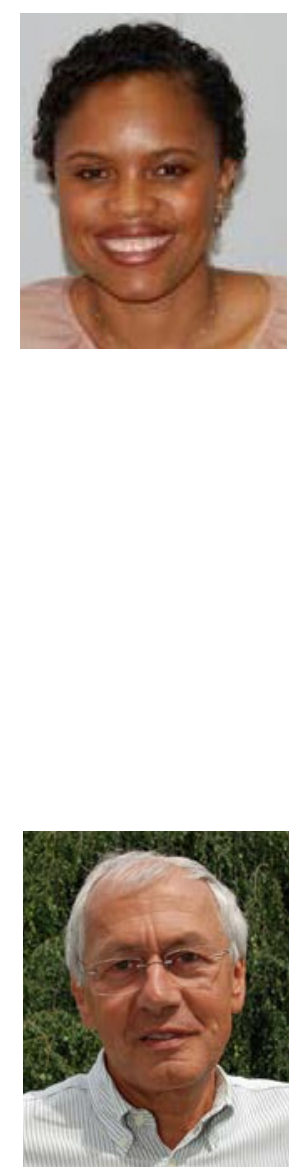
Gene E. Likens is an ecologist best known for his discovery of acid rain in North America with colleagues, for co-founding of the internationally renowned Hubbard Brook Ecosystem Study and for founding the Institute of Ecosystem Studies, a leading, international ecological research and education center. Professor Likens is an educator and advisor at state, national, and international levels. He currently holds faculty positions at Yale, Cornell, Rutgers Universities, SUNY Albany, the University of Connecticut, and recently was awarded a Chair as Albert Einstein Professor from the Chinese Academy of Science and also named Honorary Professor at Jinan University, Guangzhou, China. Professor Likens has served as President of the International Society of Theoretical and Applied Limnology, American Institute of Biological Sciences, Ecological Society of America, and American Society of Limnology and Oceanography. Professor Likens is the author, co-author or editor of 26 books and more than 600 scientific papers.

likensg@caryinstitute.org 
